\title{
QUESTÕES ECONOMICAS
}

\section{A Hulha Branca em S. Paulo}

(Ao Dr. Bento Bueno)

O maravilhoso progresso da electricidade, suas multiplicas e surprehendentes applicações, em toda a parte, exigem a immediata attenção do legislador, por que esse problema interessa não tanto aos particulares como ao futuro das nações modernas.

\footnotetext{
I-Importancia e actualidade do assumpto.

II-Aspecto historico ou a privilegiada região paulista.

II-Aspecto economico, ferro-viario e fiscal.

IV-Aspecto juridico e administrativo.

V-Projecto de lei no Congresso Paulista; sua discussão.

VI-Dados informativos e numericos.

VII-Legislação referida e conclusão.
}

\section{Jmportancia e actualidade do assumpto}

No momento presente - a regu'amentaşão e o aprovertamento da forsa hydraulica para a sua transformafão em energia electrica - é incontestavelmente o mais urgente ploblema economico a resolver, para a expansão da riqueza publica.

Basta o simples enunciado para se evidenciar que, effectivamente, se trata de um assumpto da maior opportunidade e cuja importancia é attestada pelo assombroso desenvolvimento industrial dos povos civilizados maxime do Estado de S. Paulo, onde, a respeito, 
existe um grande numero de empresas em crescente prosperidade ( $\mathrm{I}$ ).

A questão não é sómente de relevancia e actuaiidade industrial: é ainda interessante, sob o ponto) de vista economico, juridico e administrativo. Envolve ainda as mais delicadas controversias, que não terão firn, si deixarmos de ter sempre em acção os principios geraes que dominam a materia.

Como deputado ao congresso paulista, por mais de uma vez, hesitamos na elaboração de um projecto de lei sobre o assumpto, taes as difficuldades theoricas e praticas que fomos encontrando, ao examinar a questão em seus variados aspectos, cada qual o mais vasto e complexo! Entretanto, trazido á publicidade o nosso nobre intuito, nos julgamos obrigados a levar por deante a empresa, para a qual ouvimos, com grande proveito, autoridades nesta especialidade, consultando detidamente, além de diversos documentos, a legislação patria que, excepção feita do decreto federal n. 5.407, de 27 de dezembro de i904, toda ella cogita, de preferencia, do ponto de vista technico, não revelando a collaboração do jurista, pelas suas sensiveis lacunas; como, por exemplo, a da ausencia de dispositivos em relação ao que interessa ao dominio privado do Estado.

Parece-nos que formulamos um projecto de lei muito viavel, já por ter como objectivo principal o

(1) O dr. Mario Ramos, lente da Escola Naval, em seu pamplleto sobre "A Hulha Branca no Brazil", diz que-hulha branca-foi uma bella denominação imaginada por Cavour, reinventada e vulgarisada na França, por Aristides Bergér.-Segundo Pascaud,-La Houille Blanche». pag. 1 e Planiol, Dir. Civ. Franc. 1, pag. 771, nota 1, este industrial de Lancey foi o creador do inapreciavel agente inductrial ao qual deu-lhe este nome. Hulha quer dïzer energia.-Segundo Bresson não é nova a denominação Essa expressão provém, por analogia, das geleiras dos altos massiçns, de onde se despenham, á semelhança das que se observa na Suissa. Dr. Sousa Leão. Disc. na Camara dos Deputados do Estado do Rio, em 10 de Setembro de 1908. 
aproveitamento das quédas de agua existentes nas terras publicas do Estado, já por promover a uniformização ou systematização deste serviço de utilidade publica e particular, acautelando interesses geraes de grande monta, restabelecendo a ordem algum tanto prejudicada por diversas concessões que, na falta de uma lei estadual, têm sido dadas pelas camaras municipaes, sem a subordinação de um plano geral, préviamente esboçado.

Effectivamente, na sessão de 14 de Setembro de I908, apresentamos o referido projecto de lei, que ainda pende de parecer das commissões respectivas. Estando esse projecto no exame e discussão parlamen. tar, pelo immenso interesse que desperta, vamos aqui deixar consignada, com mais desenvolvimento, essa exigua contribuição que prestamos para a sollição do momentoso problema.

Pena é que alguns annos tenham decorridos, sem que o legislador providenciasse sobre esta ordem de cousas, sendo certo que innumeras concessões, á revélia dos interesses do Estado, têm sido feitas pelas camaras municipaes, tal tem sido a avidez industrial dos que mui justamente sonham fabulosos lucros, nessa brilhante série de emprehendimentos!

\section{Aspecto historico ou a privilegiada região paulista}

A commissão da camara federal incumbida de emittir parecer sobre a mensagem presidencial relatimente á electrificação das linhas suburbanas do Rio de Janeiro, sentiu difficuldade em recommendar a adopção de qualquer dos systema de tracção-tal o progresso incessante que a electricidade faz, de uma semana para outra, nos paizes modernos. "Cada instalafão nova, disse a commissão, apresenta um 
aperfeiçoamento sobre as anteriores do mesmo systema»! (2).

Sendo assim, talvez fosse preferivel adoptarmos para epigraphe deste paragrapho-o aspecto dynamico de hulha branca.

Extranhos a esse ponto de vista technico, e mesmo por aquelle motivo.. parece de avisado conselho ficarmos em nossas considerações historicas propriamente ditas.

E a primeira observação interessante a assignalar consiste no phenomeno, assás curioso, de ser dado pela natureza aos anglo saxões a hulha preta e aos latinos a hulha branca!

Realmente, ainda no anno de 1908 , a producção mundial de carvão de pedra foi de pouco mais de I 0.000.000.000 de toneladas, das quaes mais de dois terços procedentes dos Estados Unidos, da Inglaterra e da Alemanha. (3).

Os povos latinos figuram nessa estatistica singularmente na razão de um terço apenas.

As camadas do terreno carbonifero, que se constituiram no fim da éra primaria e mesmo em principio da secundaria, têm muito geral caracter geographico de formação, seus bons depositos se acham naquelles paizes. E é tal a abundancia de combustivel que a electrificação das estradas de ferro pouco tem aproveitado a energia das quédas dagua, sendo que na Norte America ella é apenas representada na vigesima parte da energia total de todas as linhas ferreas!

(2) Mensagem do presidente da Republica, de 8 de Julho de 1909. Parecer da commissão de finanças da Camara Federal, de 11 de agosto de 1900, da qual foi relator o deputado Paula Ramos.

(3) Dr. Pires do Rio, "A hulha e os povos latinos," "Jornal do Commercio" de 25 de Janeiro de 1910.

- O dr. A. Rodovalho, á 17 do mez findo, no Club de Engenharia, disse - "Que o assumpto é ainda novo no Brazil; os engenheiros brasileiro não tiveram a opportunidade de se manifestarem.» Jornal do Commercio, de 3 do corrente. 
Em compensação, os paizes latinos como a Italia, a França, a Hespanha, o Brazil (4) e especialmente o Estado de S. Paulo, são dotados de uma riqueza maravilhosa em materia de força hydraulica, cujo aproveitamento ora se inicia.

No relatorio de i 90 I, o dr. Candido Rodrigues, (quando secretario da agricultura) encarecendo esse problema economico da administração publica, escreveu o seguinte:

«S. Paulo, segundo a opinião de competentes, possue, nos seus rios, cerca de 2 milhões de cavallosvapor e, entretanto, quasi todas essas fontes naturaes de energia, utilizaveis para as necessidades da industria cada vez mais crescentes, permanecem desconhecidas dos capitaes avidos de collocação.

Só entre a capital e o Salto de Ytú, ha fundadas razões para se acreditar que o lendario Tieté póde fornecer mais de jo.00o cavallos-vapor Todos os seus affluentes notaveis, bem como outros rios que correm ou nascem em territorio paulista, são dotados de quédas de agua mais ou menos importantes, e que são quasi inteiramente desconhecidas, tanto pelo seu volume como pela altura da quéda das respectivas massas de agua. Taes são, entre outras, as quédas dos rios Paranápanema, Rio Pardo, e outros, sem falar do rio Tieté, até á sua junç̧ão com o Rio Grande»

(4) O dr. Manoel Ignacio Carvalho de Mendonça, em sua monographia "Rios e Aguas Corrente", á pags. 47 e seguintes, enumera as principaes quédas e cachoeiras do Brazil. Entre ellas cita a do Iguassú, cujo estrondo das aguas é ouvido de trinta kilometros, e r monstruosa catarata das Sete Quédas ou da Guayra, cuja differença de nivel, entre o plano superior e o plano mais baixo, é de 115 metros ou 25 metros por kilometro.

E' esta, sem duvida, a maior maravilha physica que, aos olhos do mundo, pode exhibir a America do Sul; mas digamos com tristeza-é a mais ignorada mesmo por nós". A força do Niagara é calculada em tres milhões e quinhentos mil cavallos. Pois bem, a do Iguassu' é avaliada em quatorze milhões e a da Guayra, em oitenta milhôes !!. 
Ainda, ha pouco tempo, um operoso e distincto funccionario, o sr. Amandio Sobral, ao fazer uma interessante conferencia sobre as riquezas naturaes do Esstado, a qual foi presidida pelo autor, salientou a força hydraulica dos nossos rios, alludindo, entre outras, ás cachoeiras do Orubúpungá, que é de. 447.000 cavallos, e a do salto de Itapura, que é de 54.000 cavallos, sitios esses que, em futuro não remoto, virão a ser grandes nucleos de população, importantes centros industriaes!

Ao nosso mencionado projecto de lei, apresentado ao congresso paulista, fizemos preceder uma lista das principaes quédas de agua sobre as quaes o Estado podia mandar fazer estudos definitivos, e entre ellas destacamos a notavel cachoeira do Juqueriquerê, de propriedade do Estado, na distancia de 150 kilometros desta capital e que desce mais. de setecentos metros em dors ou tres kalometros, sendo de um incalculavel valor e de uma assombrosa pujança!!

Essa cachoeira, em altura, está muito superior á de Ribeirão das Lages, no Estado do Rio, que, assignalando apenas trezentos metros, até ha pouco, se acreditava ser a que marcava o record das quédas, na America do Sul. Essa cachoeira ainda está apenas duzentos metros abaixo damais alta quéda do globo, a de Vauri, na Suissa, que mede 900 metros de altura!

Comparando a nossa carta geographica com qualquer outra dos Estados da Republica, vê-se que, em força hydraulica, em nosso paiz, nenhuma zona foi mais dotada pela natureza, do que a de S. Paulo. Basta attender-se para a carta physica do Estado, levantada pelo dr. João Pedro Cardoso, para ver-se quão maravilhosa é a disposição dos nossos rios, todos elles ricos de cachoeiras! Basta considerar a direç̧ão geral do Tieté, que atravessa o Estado de S. E. a 
N.O., partindo da serra do mar e indo despejar suas aguas no Paraná, notando-se que elle aqui, na capital, está a 7 i 7 metros sobre o nivel do mar e chega ao Rio Paraná com 27 I metros, formando uma verdadeira escada e onde encontramos o majestoso salto de Itapura, o estupendo salto de Avanhandava, e tantos outros. Como esse rio, são ainda o Paranápanema, o Paraná, o Parahyba e o Ribeira, com os seus mil affluentes, além dos demais rios que banham a região das terras devolutas, como os que se despenham como filetes de prata, por toda a cordilheira do Paranápiacaba ou serra do mar. Todos têm innumeras cachoeiras, saltos e corredeiras, embora com trechos perfeitamente navegaveis. (5).

Nos Estados Unidos, a força hydraulica acha-se concentrada nas regiões das montanhas Rochosas ou da California, nas vertentes dos Alhenhys e do Niagara-ao passo que, em S. Paulo, por toda parte encontra-se disseminada aquella grande riqueza, como que desafiando a indifferença secular dos seus habitantes; que só agora estão despertando aos raios de uma nova alvorada!

Temos fortes razões para duvidar que exista, no globo, uma área igual á occupada pelo Estado de S. Paulo, e que seja mais bem favorecida, ou antes, tenha melhor distribuida, a força hydraulica, tal a . brilhante e estupenda dispersão dos seus saltos e ca. choeiras!

(5) Cumpre reconhecer que a administração publica não se tem descuidado da exploração dessas riquezas que se encontram no territorio do Estado. No paiz e no extrangeiro são conhecidos os notaveis trabalhos da Commissão Geologica e Geographica, á frente da qual se acha um engenheiro tão illustre e talentoso quão modesto, o dr. João Pedro Cardoso, cujos serviços ainda ha pouco foram enaltecidos - "como mudelo a seguir" pelo Boletim da Sociedade Geographica de Pariz e pela Revista das Obras Publicas de Lisboa. 
Certo disso, Enrico Ferri, em sua conferencia, sobre as maravilhas do seculo XX, nesta capital enalteceu as nossas quédas de agua, ás quaes affirmou estar reservado os mais altos destinos e Bryan, em sua recente e rapida visita á S. Paulo, disse que ao sahir desta terra, só levava um pesar, o de não ter podido vêr as nossas princıpaes cachoerras das quaes já havia tido a mais conceituosa noticia!

Generalisando o problema que tanto interesse desperta no seu detalhe, podemos affirmar a verdade historica seguinte; si por fatalidade geologica, o carvão de pedra ou a hulha preta favoreceu as regiões do globo povoadas pela raça anglo-saxonia, dando-lhe uma superioridade no terreno industrial, por outro lado, em compensação, os paizes occupados pela raça latina foram mais dotados da hulha branca que, ao despertar do seculo XX, assombra a intelligencia humana com as suas brilhantes revelações ou surprezas, com as mais estupendas maravilhas.

O economista Leroy Beaulieu, a proposito do mesmo assumpto, escreveu: "La houille blanche enleverá aux centrées riches en carbon leur monopole industriel que leur avait donné le vapeur et comme la puissance politique est souvent la consequence de la puissance economique, il doit en resulter des changements dans l'e, quilibre même du monde. Un ére nouvelle souvre devant nous, ére de grande prosperité si nous savons mettre energiquement nos forces hydrauliques en valeur».

Aguardemos esse brilhante e não remoto futuro. Antes de tudo, porém, reconheçamos a exactidão do seguinte conceito de um publicista contemporaneo, ao escrever sobre a hulha e os povos latinos:- A debatida questão da "inferioridade da raça latina" é uma fantasia creada por alguns escriptores que tudo 
procuram explicar pelo factor-homem - que elles conhecem por contacto, sem levar em conta as condições geologicas e geographicas do logar e as industrias da época, que elles não podem apreciar por falta de cultura scientificas.

\section{Aspecto economico, ferro-viario e fiscal}

a)-Em relação ao interessante ponto de vista economic' não nos pođemos furtar ao prazer de fazer nossas as seguintes considerações que se encontram no bello pamphleto do dr. Mario Ramos, sobre a *Hulha Branca no Brazil», pags. I6:

"Entretanto, os progressos assombrosos realisados nestes dous ultimos lustros nos apparelhos receptores de energia sob a forma electrica, para transformação em luz, calor, movimento, effeitos chimicos, effeitos radiantes etc., deviam ser entre nós o grande incentivo que fizesse de sul a norte florescer em cada centro uma destas usinas, que recebendo as aguas encachoeiradas da torrente proxima, irradiasse por dezenas de kilometros a força, a luz e o calor, ás populações afadigadas e atrazadas nos meios já obsoletos de prover á existencia.

E' que a energia, sob a fórma electrica, como que se dilúe em infinitas applicaçōes: a lampada que brilha incandescente em seu filamento ou que flammeja intensamente no arco luminoso, o motor que impulsiona o tramway ou a machina-ferramenta robusta e seguramente controllada, a resistencia que irradia o calor, o forno electrico que reduz os metaes, a ampola que produz os plenomenos de fluorescencia e que emitte irradiações que atravessam os corpos opacos, a onda hertzianna que á dezenas de kilometros vai ser revelada e utilizada, as altas trequencias 
que produzem os effeitos therapeuticos, etc., etc., tudo é energia electrica e, por consequencia, tudo pode ser hulha branca.

A industria da electro-metallurgia e da electro chimica, com o advento do forno electrico, e os trabalhos memoraveis de Moissan pode-se affirmar, tem um horizonte sem limites: a fabricação dos aços ordinarios, nos aços finos, das ligas do ferro do aluminio, do silicio e seus derivados, do cobre, do zinco, do nickel, do phosphoro, dos carburetos metallicos, do manganez; as operações da electro-chimica dos chloratos, da soda, dos hypochloritos, dos nitratos, das cyanamidas; a galvanoplastia, a galvanização, a producção do acido azotico, a fixação do azoto e da ozona atmosphericos, do oxigeno e do hydrogeno, o embranquecimento das materias textis, etc., etc., tudo é energia electrica e, por consequencia, tudo é o triumpho da hulha branca».

Para o Brazil, pois, a exploração da industria da hulha branca constituirá uma epoca memoravel na sua evolução economico-social, ella fortalecerá a lavoura, levando a energia mecanica a infimo preço e immediata applicação para o movimento das machinas e dos utensilios de beneficiamento; revolucionará as industrias existentes pela reducção do custo da força, diminuição da mão de obra e dos espaços das installações; estabelecerá as novas industrias da electrometallurgia e da electro-chimica, fazendo surgir as riquezas latentes do nosso solo; eliminará as grandes distancias pela rapidez e conforto dos comboios electricos; creará positivamente uma éra nova, éra de grande prosperidade, que será a éra da hulha branca!

b) - Sobre o ponto de vista ferro-nario, o aproveitamento da hulha branca é uma questão vencida. Pode-se affirmar, com a opinião da engenharia moderna, 
que o problema da traç̧ão electrica nas estradas de ferro está technicamente resolvido.

Convencido dessa verdade, o governo brazileiro endereçou, em 8 de Julho de 1909, uma mensagem ao Congresso Nacional, suggerindo a ideia da electrificação da Estrada de Ferro Central, na parte que serve aos suburbios da Capital Federal, afim de attender ao serviço de transporte que só de passageiros, em I 908, attingiu a vinte milhões, duplicando assim em cinco annos!

Essa mensagem foi objecto de estudo no Congresso e sobre ella foi emittido um interessante parecer (6), relatado pelo deputado Paula Ramos. Eis algumas de suas apreciações:

Nos paizes como o nosso, em que o carvão é caro e a energia electrica pode e deve ser barata, a electrificação está sendo feita quer nas linhas novamente construidas, quer nas que adoptaram a tracção á vapor. E' o que se observa na Suissa e na Italia. Em algumas outras estradas de ferro, como em Londres, fez-se a electrificação para que pudessem supportar a concorrencia dos tramways existentes ou para evitar o estabelecirnento de novas linhas de tramways. Em outras, a mudança de tracção opperou-se pela necessidade de satisfazer o transporte de passageiros. Foi o que se deu, por exemplo, na linha de Southport, que serve os suburbios de Liverpool. Nessa linha circulavam com a tracção a vapor 45 trens e depois de feita a transformação começaram a circular $65 \mathrm{em}$ cada sentido.

Não ha mais quem conteste que nas regiões em que o preço do carvão é alto, a tracção electrica é muito mais economica comparada á tracção a vapor

(6) Vide o parecer sob n. 94, de 1909, publicado no "Diario do Congresso" daquelle anno, pag. 1187 
e que as despezas de trafego das estradas de ferro de tracção a vapor são, em geral, mais elevadas do que quatro a oito vezes que as de tracção electrica."

- Convem lembrar que sobre o assumpto da electrificação de quaesquer outras ferroviarias o decr. legislativo federal sob n. 5.646, de 22 de Agosto de I 905 estabelece differerentes providencias.

c)-Sob o ponto de vista fiscal, é incontestavel que a exploração das quédas d'agua, do dominio privado do Estado, dará, no futuro, os mais brilhantes resultados.

Essa enorme riqueza, até o presente inteiramente desaproveitada, poderá constituir um poderoso factor da receita orçamentaria, se merecer a devida attenção dos poderes publicos.

Com o desenvolvimento extraordinario da despesa publica e dos compromissos do Estado, dado o facto real de não ser illimitada a capacidade tributaria das classes populares, o unico recurso será o proprio Estado explorar, directa ou indirectamente, esse opulento patrimonio, a exemplo da Prussia onde dois terços da receita são formados pelo rendimento dos bens do Estado. As apreciações que ainda poderiamos fazer sobre este interessante ponto encontram se no discurso que pronunciamos no Congresso Paulista e que mais adiante resumimos.

\section{Aspecto juridico e administrativo}

a) -No tocante ás quédas d'agua existentes na terras devolutas, nenhuma duvida pode ser seriamente suscitada, porquanto trata-se de bens patrimoniaes do Estado e dos quaes este pode dispor, ao seu livre alve. drio, ex-vi do art. 64 da Const. Fed.

Esse art. é assim expresso:- "Pertencem aos Estados as minas e as terras devolutas situadas nos 
seus respectivos territorios, cabendo á União sómente a porção do territorio que for indispensavel para a defesa das fronteiras, fortificaçðes, construcções militares e estradas de ferro federaes».

Como pessoa juridica, o Estado pode dispôr desses bens que constituem o seu patrimonio ou o seu dominio fiscal.

"Como proprietario, o Estado, por seus organs competentes e sob as prescripções geraes da lei, pode administrar e alienar os bens do seu dominio privado. A administração pertence, em geral, ao poder executivo por intermedio dos ministerios respectivos, especialmente do da fazenda, a cujo cargo se acha a administração do dominio nacional, quando não esteja ella expressamente affecta a outro ministerio» (7).

No dominio fiscal, portanto, é esse o estado presente da questão que ora examinamos. (8)

b) -Relativamente ás quédas d'agua existentes em qualquer rio particular, cuja nascente, todo o percurso e fóz sejam encontradas em terras de um só proprietario, tambem nenhuma duvida pode ser suscitada, á vista do que preceitúa o art. 72 \& 7 da const. fed., que garantiu o direito de propriedade em toda sua plenitude, salvo de desapropriação por nepag. 53 .

(7) Dr. Rodrigo Octavio «Do Dominio da União e dos Estados»

(8) Comquanto muito acertadamente se entenda que a alienação do dominio privado do Estado depende de expressa autorisação do poder legislativo, o certo é que a Constit. Fed. silenciou em relação ao assumpto. Posteriormente, á lei n. 23, de 30 de Outubro de 1891, art 2, letra $d$, preceituou a respeito, sendo que o dec. 7.751, de 23 de Dezembro de 1909, que regula a administração geral da fazenda nacional, faz, de modo claro, depender da autorisação legislativa, tal alienação.

A const. deste Estado, de 9 de Julho de 1905, art. 20, n. 11, lettra e, dispoz vagamente sobre "os proprios estaduaes» em cuja expressão se deve entender todo o dominio privado, sua constituição e alienação, arrendamento, permuta, e todos os actos necessarios para a completa gestão do patrimonio do Estado. 
cessidade ou utilidade publica, mediante indemnisação previa.

A intervenção do Estado, neste caso, só se admitte no que for referente á medidas puramente administrativas ou policiaes, de mera fiscalisação da respectivá exploração industrial, a ben da segurança publica.

Os proprietarios das quédas d'agua podem, pois, livremente exploral-as, guardadas as disposições da lei em beneficio da mesma exploração industrial.

No seu "Esboşo do Cod. Civ.", art. 33I, in fine, diz Teixeira de Freitas: - "Os demais rios que não reunem os requisitos dos rios publicos e os que nascem, córrem e desaguam em terreno de dominio pri. vado, são rios particulares e pertencentes aos donos dos respectivos terrenos».

$\mathrm{Na}$ Consolidação das Leis Civis "aquelle jurisconsulto sustenta a mesma theoria quando, de accordo com o alvará de I 7 de Agosto de I775, preceituou, no art. 898:- $-\mathrm{O}$ dominio e a posse das aguas, quando são particulares, pertencem aos donos dos predios onde nascem»

Lafayette, no seu livro sobre o "Direito das

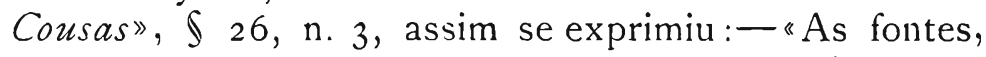
as nascentes e as correntes de agua particulares, na extensão em que atravessar o terreno, pertencem ao proprietario por virtude do dominio adquirido. $E$ accrescenta:- $\mathrm{O}$ rio particular que serve de divisa entre predios de diversos donos, pertence a cada um dos proprietarios, em todo o comprimento de sua testada, até a linha tirada pelo centro do alveo».

Carlos de Carvalho, em sua "Nova Consolidafão" art. 2 I 4, com a mesma uniformidade de vistas, assim preceitúa:- *Entre os bens particulares comprehendem-se:-as fontes, nascentes, aguas correntes, rios 


\section{- I93 -}

não navegaveis, e os de que não se fazem os nave. gaveis ou não caudaes, na extensão em que atravessam o dominio particular, salvas as servidões do art 16 , $\int \mathbb{I}$ I, 2 e 3, da lei n.60 I, de I 8 de Setembro de 1850.

$\mathrm{O}$ dr. Alfredo Valladão, que recentemente estudou o assumpto para organisar o Cod. das Aguas da Republica, assim exprimiu-se, na sua monographia sobre "Rios Publicos e Particulares"; pag. 82:"Sendo de um só proprietario ambas as margens de um rio particular, elle é o senhor exclusivo das aguas respectivas; pode pois aproveital-as, como entender, para a montagem de usinas electricas, fazendo as necessarias derivações, embora essas derivações privem os proprietarios dos predios inferiores do commodo que aquellas aguas lhes proporcionavam

Em relação aos rios particulares de propriedade commum. as suas aguas se repartem entre os co-senhores por evitar discordias, requerendo alguns delles e provando que tem condomino pro-indiviso ou alternadamente (9).

No dominio particular, esse criterio que sempre tem prevalecido e consagrado pela jurisprudencia dos tribunaes (1o) deve ser commum ou applicavel tanto aos rios como ás quédas d'agua.

c) - Em relação as quédas d'agua existentes nos rios publicos ou nas correntes volumosas e perennes, de agua, que são de uso conmum, antes de tudo convém referirmos, embora perfunctoriamente, sobre as seguintes questões:- Em nosso direito patrio como são definidos os rios publicos ?-- a quem compete legislar

(9) Resol. de 17 de Agosto de 1775; Almeida e Sousa, "Trat. dàs Aguas" $§ 69$; Lafayette, "Direito das Cousas" $§ 124:$ Borges Carneiro, "Direito Civil" vol. $2, \S 30$ n. 6, § 31 n. 21.

(10) A propriedade do; ribeirinhos sobre os rius não navegaveis, quandu estes não sejam caudaes perennes de que se façam os navegaveis, é consagrada desde o Acc. do Sup. Trib. de Just. do Imp. de 27 de Julho de 1849. 
sobre taes rios? - a quem assiste a competencia de lesislar sobre a explorafão das quédas d'agua?-qual o verdadeiro criterio a seguir.

- Rios Publicos, segundo a ord. do liv. 2, tit. 26 $\llbracket 8$, são os navegaveis e aquelles de que se fazem os navegaveis, si são caudaes, que corram em todo tempo. Por sua vez, rio navegavel, ủefine Teixeira de Freitas, em seu "Esboço",:- "são aquelles em que a navegação é possivel, natural ou artificialmente, em todo o seu curso ou em parte delle, a panno, remo ou á sirga, por embarcação de qualquer especie, como tambem por jangadas, pranchas e balsas de madeira" ( I 1). Esta noção tem sido geralmente aceita. - A quem compete legislar sobre os rios publicos, á União ou ao Ẽstados?

Examinemos a questão desde a legislação romana onde tem assento o direito nacional. (I 2 ).

(11) O dr. Alfredo Valladão na "Exposição de Motivos» a que fez preceder as suas bases para o "Codigo das Aguas da Republica," pag. 13, diz o seguinte:- Estabelecido que o texto da Ord. Ph. não trata dos rios não navegaveis, a que regimen estão elles sujeitos pelo direito patrio? Ao regimen do direito romano; quando conforme com a bôa razào e com a equidade, segundo a lei de 18 de Agosto de 1769 . Ora, o dominio publico era bem amplo por este direito." Mas adiante accrescenta:- «Sem desconhecer a existencia de correntes do dominio privado, pelo nosso direito vigente, entendo que o dowinio publico se estende a correntes fluctuaveis. Assim no estado actual do direito patrio, se devem considerar publicos os rios navegaveis ou fluctuaveis e aquelles que os mesmos se fazem, si são caudaes que corram a todo tempo.»

(12) O dr. Araripe Junior, no "Jornal do Commercio" de 24 de Outubro de 1909, em um extenso artigo assim opina:- "Não pertenço ao numero dos que pensam que a Const. da Rep., distribuindo o dominio dos rios (sic) por um artificio resultante da combinação do art. 34 n. 6 e 63 n. 2, entregou á União todos os rios navegaveis que banliam mais de um Estado ou se extendam a territorios extrangeiros e, a cada um dos Estados os seus rios navegaveis territuriaes e os candaes de que elles se formam." No mesmo "Jornal", a 14 de Novembro seguinte, o $d r$. Francisco de Castro Junior sustenta, com grande vantagem, a doutrina opposta, que nos parece a mais justa.

Tambem o dr. Raul Penido, num extenso artigo publicado no "Jornal do Commercio", de 23 de Dezembro de 1909, de accordo com a opinião do dr. Araripe, explanou o assumpto, encarando-c, com mais especialidade sobre o ponto de vista da-Irrigação. 
Entre os romanos, o dominio das correntes peren. nes e volumosas era de uso commum ou publico. No intuito de ser regulado esse uso, ninguem então, podia usar livremente das aguas dos rios publicos navegaveis sem a licença do principe.

O regimen feudal alterou a norma romana, modificando profundamente a condição juridica dos rios. Assim que "confundindo o direito de soberania com o direito de propriedade, os cursos d'agua entraram tambem para o patrimonio do principe, e foram enumerados entre os direitos regios. E, em consequencia das lutas entre principes e feudatarios, distinguiram.se os navegaveis dos não navegaveis. Os primeiros ficaram reservados para o dominio do principe; os segundos, bem como os seus respectivos leitos, foram submettidos á alta justiça dos senhores que delles gosavam como donos, dispondo ainda dos mesmos mediante concessões a particulares. (i ${ }_{3}$ )

E' desse regimen que procede a denominação de direito realengo. (I 4 )

Prevalecendo essa corrente anti-romand, ella pe. netrou nas ordenações do reino que, inspirando se na lição do direito feudal (Liv. II dos feudos sob a rubrica quz sunt Regalza, tit. LVI), deixou expresso: Pertencem aos direitos reaes: "as estradas e ruas publicas antigamente usadas e os rios navegaveis e os de que se fazem os navegaveis si são caudaes que corram em todo tempo. E' posto que o uso das estradas e ruas publicas e dos rios seja igualmente commum

(13) Pacelli, "Acque Pub iche": pag. 5; dr. Alfredo Vallaclĩo,. Exposição de Motivos do "Cud. das A guras" pag. 9.

(14) Antigamente os reis confundiam as suas propriedades com o dominio privado ou fivcal do Eitado. Só depois que os Estados Geraes deram exemplo de cuidar-se da propriedade pubica é que, tal dominio, foi se destacando de morlo a haver distinç̧ão entre bens do Estado e bens do soberano reinante. De. Jacob "Science des Finances" 50. 
a toda gente e ainda a todos os animaes, sempre a propriedade dellas fica no patrimonio real»-Ord. Liv. II. Tit. XVI \8).

Surgiu dahi a natural opposição de alguns que entendiam era livre se fazerem obras não só nos rios não navegaveis como nos proprios navegaveis, uma vez que não houvesse prejuiso publico, e tão crescente foi ella que justificou o alvará de 27 de Novembro de $\mathrm{s} 804$, dando ao proprietario direito de fazer canaes ou levadas para regar suas terras ou para esgottar as innundadas, requerendo ao juiz, mediante parecer de louvados, a designação do lugar mais commodo e apropriado, ainda que em terreno alheio, cujos donos seriam indemnisados dos prejuizos que porventura soffressem. Teixeira de Freitas. Consol. art. 894, nota I 2) constituindo.se a servidão de aqueduto independente de autoridade regia, ao contrario do principio ainda dominante de todas as nações sujeitas ao feudalismo. (Almeida e Souza, Tr das Aguas, \$24).

O dito alvará, I 5 annos depois, em I 8 I9, foi mandado applicar ao Brasil e era essa a situação em que a Const. do Imp. veio difinir os direitos e prerogativas da corôa e esses direitos reaes passaram para o dominio nacional. (Const. do Imp. art. I I 5). ( I 5).

A competencia, em materia de navegação, no regimen monarchico, achava-se assim discriminada:

a)-Competia á Assembléa Geral legislar sobre a navegação dos rios interiores que desaguassem no mar, ou se dirigissem a territorios extrangeiros, ou percorressem mais de uma provincia, ou fossem divisas de mais de uma dellas; $-b$ ) - Competia ás Assem-

(15) Dr. Alfredo Valladão "Rios Publicos e Particulares» pag. 77 e seguintes. $-d r$. Francisco de Castro . Tunior, "O duminio das Aguas e a Energia Electrica" artigo no Jornal do Commercio, de 14 de Novenbro de 1909. 
bléas Provinciaes legislar sobre os rios que não pertencessem á uma das classes mencionadas e estivessem dentro de seu territorio, salvo si taes rios fossem necessarios a certos serviços geraes; $c$ )-Competia ás Camaras Municipaes, legislar sobre os rios, fóra das classes supra, dentro do territorio do municipio, salvo a restriç̧ão mencionada ( 16 ).

- Perante o actual regimen politico ou de preceituario contido no art. $72 \$$ i 7 da Const. Fed., de inteira applicação ao assumpto, é incontestavel que foi profundamente alterado o direito anterior.

O dominio publico, $\boldsymbol{e} \mathcal{X}-\boldsymbol{v} \imath$ da mesma Const., foi dividido em federal, estadual e municipal, e, sendo assim, é manifesta aquella triplice competencia, tanto mais quanto a União reservou para si partes do territorio nacional (arts. 3 e 64) e concedeu aos Estados as terras devolutas nos respectivos territorios, cuja posse abrangeu forçosamente o systema fluvial. ( I 7 )

"Aos Estados, cabe o dominio dos rios que correm por seus territorios. Elles podem regular seus usos publicos de derivação e outros, uma vez não se tornem, com isso, prejudicial ao uso publico supremo da navegação. Esta, por sua vez, compete á União, não como consequencia da propriedade, mas como consequencia da soberania que a elle pertence e em virtude da qual regula o commercio internacional e nacional»

(16) Dr. M. I. Carvalho de Mendonça, "Rios e Aguas Correntes", pag. 102, Uruguay "Administração das Provincias," pag. 78. Consulte-se a lei de 29 de Agosto de 1829, e o Act. Add. que determinaram uma corrente liberal em relação ao assumpto, e a lei n. 105 , de 12 de Maio de 1840, bem como o Av. de 6 de Janeiro de 1860, em sentido mais centralisador.

(17) Estes dois argumentos fundamentaes foram desenvolvidos pelo dr. Alfredo Valladĩo, no seu livro sobre "Rios Publicos", pags. 48 a 76; pelo dr. M. I. C. de Mendonsa, "Rios e Aguas Correntes"; pag. 119 e pelo $d r$. Castro Junior, log. cit. 
Em relação ao que vem de ser succintamente exposto, podemos de accordo com a opinião, dos jurisconsultos patrios que têm se preoccupado com esta especialidade (r8), concluir pela forma seguinte:

$\mathrm{I}-\mathrm{O}$ dominio publico dos rios de uso commum pertencem precipuamente, aos Estados;

II-A União cabe, o dominio dos rios que limitem qualquer ponto do territorio nacional com uma nação extrangeira;

III-Pertencem aos municipios, os rios que dentro do territorio delles, tiverem sua nascente, todo o percurso e fóz (19).

Determinada, em suas linhas geraes, a competencia para legislar sobre os rios publicos, vejamos agora, sem offensa aos principius geraes expendidos, qual o fundamento em que se assenta a indiscutivel competencia de os Estados legislarem sobre a exploração da força hydraulica dos rios comprehendidos nos res. pectivos territorios.

Ao discutir este delicado assumpto, eis o que dissemos, na camara dos deputados deste Estado, em sessão de 14 de Setembro de I908:

Antes de tudo, cumpre examinar a competencia do Estado em legislar sobre esta especialidade.

No tocante ás quédas de agua existentes nas terras devolutas, nenhuma duvida deve ser suscitada, porquanto trata-se de bens patrimoniaes do Estado e dos quaes pode dispôr ao seu livre alvedrio, ex.vi do art. 64, da Constituição Federal.

(18) Dr. Alfredlo Valladão, "Rios Publicos e Particulares", pag. 57 e 76. Dr. M. I. Carvalho de Mendonça, "Rios e Aguas Correntes", pag. 121 .

(19) Como se vê, nús accrescentamos apenas mais o seguinte requisito :--"E todo o percurso". 
Quanto ao que se refere aos rios publicos e particulares, o primeiro ponto á affirmar é que a Constztunça Federal, no art. 34, paragrapho 6, apenas reservou o direito de legislar sobre a navegrcão dos rios que banhem mass de um Estado cu se extendem a terrtorios extrangervos. $\mathrm{Na}$ conformidade do preceito fundamental, a lei federal n. ro9, de i4 de outubro de I 892, fixou os casos de competencia dos poderes federaes e estaduaes para resolverem sobre o estabelecimento de vias de communicação fluviaes ou terrestres entre a União e os Estados e destes entre si.

Como se vê, a Constituição Federal, traçando o criterio interestadual e internacional para a União legislar sobre a navegação, nada estatuiu quanto á força hydraulica dos rios existentes nos respectr. vos territorzos dos Estados e, sendo assim, a hyputhese está comprehendida na latitude do art. $6_{5}$, paragrapho $2 .^{\circ}$, que faculta aos Estados "em geral todo e qualquer poder ou direito que lhes não for negado por clausula expressa ou implicitamente contida, nas clausulas expressas da constituição». Tanto é verdade que, no art. $35, \mathrm{n} .2$ da Const., o legislador permitte a concorrencia de poderes federaes e estaduaes em tudo quanto interessar ao desenvolvimento da industria em oreral. Estes dispositivos são fundamentaes e não permittem duvidas quanto á alludida competencia.

Accresce que, dispondo sobre o aproveitamento das quédas de agua, o Congresso Nacional, pela letra do art. 23, da lei orçamentaria I. I 45, de 3 I de de. zembro de i903, e, posteriormente, o decreto n. 5.407 , de 27 de dezembro de i 904, firmaram a competencia da União sómente no que interessar aos serviços federaes.

Em face desses dispositivos, parece-me não restar duvida alguma, quanto á extensão da competencia 
estadual, que, aliás; já tem sido exercida em alguns Estados, como os do Rio de Janeiro e da Bahia.

No que diz respeito á exclusiva competencia estadual, quanto ao legislar.sobre o assumpto referente aos rios publicos e á exclusiva competencia das municipalidades sómente quanto ás quédas de agua existentes em ros cujas nascentes, percurso e fóz sejam comprehendidos pelos respectıvos territorzos, si não bastassem o dispositivo citado da Constituição Federal e o facto de não haver o Estado declinado, expressamente, dessa sua privativa attribuição - eu me reportaria ainda a outros principios geraes que regem a questão.

E' ao Estado a quem, principalmente, compete exercer, sobre a servidão publica dos rios navegaveis, a policia, a segurança e a tutela administrativa, em geral, e dahi lhe decorre a attribuição, uma vez satisfeitos aquelles requisitos, de tambem conceder a licença para o exercicio do direito privado da exploração da força hydraulica, que assiste aos proprietarios ribeirinhos. Quanto aos rios particulares, é certo que o direito do proprietario não é limitado por servidão publica; essa circumstancia, porém, não exclúe ainda a intervenção do Estado, quanto á policia e segurança publica na exploração da força hydraulica, afim de evitar-se, tanto quanto possivel, o constante perigo desse fulminante agente industrial da electricidade.

$\mathrm{O}$ dr. Alfredo Valladão, assim resumiu a theoria que vem de se ser succintamente exposta (20).

(20) Dr. Alfredo Valladão, "Codigo das Aguas" pag. 63. A' pag. 73 encontra-se ainda os seguintes dispositivos da mais conveniente applicação: O dono de um predlio atravessado por uma corrente pode servir da quéda de agua deterininada pelo nivel medio da entrada sobre o predio e o nivel medio da sahida. Si o curso de agua separa dois predios pertencentes a diversos proprietarios o direito de se servir da quéda pertence a cada um delles pro indiviso, sobre todo o percurso coinmum, salvo titulo ou posse em contrario. Em ambos os casos, o exercicio deste direito fica subordinado á autorisação legislativa. 
As aguas publicas de uso commum, bem como o seu alveo e margens pertencem: $a)-A^{\prime}$ Unzão quando situadas no territorio do Acre ou em qualquer outro territorio que a União venha adquirir emquanto o mesmo não se constituir em Estado ou for incorporado a algum Estado;-quando servem de limites com as nações, vizinhas;-finalmente, quando situados na zona de dez leguas, contigua aos limites da Republica com estas nações;-b)-Aos Estados em qualquer outra hypothese salvo o caso do dominio municipal;-c) - Aos Muncipios quando exclusivamente situados em seus territorios, respeitadas as restricções que possam ser impostas pela legislação dos Estados.

Como se vê a divisão tripartita do dominio publico, é a mesma que deve ser adoptada quanto ás quédas dos rios. As quédas produzidas pelas aguas dos rios publicos pertencem ao dominio da União, do Estado e do Municipio, tal seja o proprietario dos mesmos conforme a theoria já exposta.

- No Estado de S. Paulo, qual o criterio a seguir para definir-se a competencra estadual e munucrpal?

Antes de tudo vejamos o que, com muita sabedoria, dispõe a lei estadual n. 30 , de 13 de Junho de 1892 , em seu art. 30 .

Ahi se preceituou o seguinte:- "Desde que ligarem-se duas ou mais linhas de bonds situadas em municipios differentes, serão consideradas estradas de ferro estaduaes. Esta ligação não pode ser utilisada sem prévia licença concedida pela administração do Estado que collocará a estrada sob o regimen da pre. sente lei. 
O precedente está brilhantemente firmado e nelle devem inspirar os legisladores quanto ao assumpto da exploração da força hydraulica. (2 I )

Accresce que o assumpto já foi objecto de estudo de uma das commissões do senado paulista e da qual foi relator o dr. Almeida Nogueira que, em parecer de 25 de setembro de 1908 (22), assim exprimiu-se:

"Pódem os Estados legislar sobre rios navegaveis?

A questão não nos interessa, sinão em relação ao Estado de S. Paulo.

$\mathrm{O}$ art. 20, n. I I, letra d, da Constituição de S. Paulo dá competencia ao Congresso do Estado para legislar sobre "obras publicas, estradas, canaes e navegação no interior do Estado, nos termos da Constituição Federal».

(21) Pur occasião de discutir-se a concessão de um privilegio sobre a extração do ouro do leito do rio Ribeira de Iguape, na sessão do senado paulista de 23 de Dezembro de 1908 , o $d r$. Dino Bueno, entre outras considerações expendeu as seguintes:

"A quem compete legislar ou dispor sobre tal materia?

A Commissão de Constituição desvendou tambem, perfeitamente, o estado actual do nosso direito, em relação a essa competencia.

$A^{\prime}$ União compete legislar subre o direito substantivo, sobre o direito de propriedade das minas, prescrevendo, de accordo com o art. 72, paragrapho 17 da Constituição Federal, as restricções ou limitações que possam ser aconselhadas pelo bem publico em favor da exploração desse ramo de industria.

Aos Estados compete legislar sobre as minas que se achem situadas em seu territorio, assim como ao municipio sobre aquellas que se encontrem em territorio municipal: não sobre o direito substantivo, sobre o direito de propriedade das minas, que é de direito civil, e que, como vimos, é da competencia da União, mas sobre o processo, sobre o modo ou as formalidades para se fazerem as concessões de mineração em terrenos publicos, sobre as clausulas com que taes concessões devam ser feitas, sobre as contribuições a que devam ser sujeitos os concessionarios, em summa, todas as normas $\epsilon$ todas as regras que devam ser impostas á exploração, a bem do exeruicio e desenvolvimento dessa industria."

-Entendemos que relativamente á exploração da força hydraulica, outro criterio não se deverá seguir.

(22) Parecer sob n. 57, de 1908, do senado paulista, sobre a exploração do rio Ribeira de Iguape. 


\section{$-203-$}

Nesta restricção final, certamente, o nosso legislador constituinte faz referencia ao art. 34, n. 6 , da Constituição da Republica, que dispõe o seguinte, entre as attribuições privativas do Congresso Nacional: «Legislar sobre navegação dos rios que banhem mais te um Estado, ou se extendam a territorios extrangeiros.

A mesma soluçâo, além de consagrada pelo elemento historico (Acto Addicional á Const. do Imp., art. ro, n. 8) é confirmada pela doutrina e pela jurisprudencia patria (Rodrigo Octavio, Do Dominio da União e dos Estados, Cap. II, \3, ibı not. 6o, pag. 46.» Ahi se encontram differentes julgados.

Como se vê, por este parecer, a competencia estadual em materia de regulamentação da exploração dos rios e, portanto, de suas quédas, é indiscutivel e assenta.se no proprio texto da Const. Federal.

-Quanto ao aspecto administrativo da questão, longe iriamos si, mesmo na generalidade, nos occupassemos das condições technicas que devem ser estabelecidas para a distribuição da energia electrica.

Da mesma forma nos enunciamos quanto ás prescripções geraes, relativas á segurança publica, á manutenção e escôamento das aguas, ao accesso dos predios occupados pelas installações, ás communicações telegraphicas e telephonicas, á liberdade da circulação de quaesquer vehiculos e muitos outros detalhes (23).

Uma questão. porém, interessante no que diz respeito á administração, consiste em indagarmos a qual dos poderes compete fazer as concessões.

(23) Devemos á gentileza do snr. dr. José Luiz Coelho, digno director da seç̧àc da viação, da Secretaria da Agricultura, as copias das leis francezas de 15 de Junho de 1906, 21 de Março de 1908, snbre a exploração de furça hıdraulica e que podem ser consultadas com grande aproveitamento. 
Muitas têm sido as concessões requeridas, ora ao poder executivo, ora ao poder legislativo; outras têm sido concedidas por ambos os poderes conjunctamente, com os privilegios de estradas de ferro; e, finalmente, ainda outras, pelas camaras municipaes, havendo uma completa anarchia nesta ordem de cousas.

$\mathrm{E}^{\prime}$ indispensavel estabelecer-se um regimen definitivo a respeito, de modo a habilitar a administração publica a encaminhar proveitosamente o desenvolvimento industrial do paiz.

Por occasião da discussão do privilegio para a extracção do ouro do leito do rio Ribeira de Iguape, no senado paulista, em sessão de 22 de Outubro de I 908, o dr. Herculano de Freitas, agitou questão identica, assim exprimindo-se:

«E, por força dessa legislação a que me venho referindo, legislação não só propria como extranha, pois que além das disposições do livro II das Ordenalções, nos regiamos por varios alvarás e leis do tempo do Imperio, tendo tambem como subsidiarios do nosso, o direito allemão e o direito chileno, em materia de minas, e, sr. presidente, parece-me que, em virtude das disposifôes e das praxes estabelecidas no tempo do Imperio ácerca de concessões de minas, não é ao poder legislativo que incumbe fazer taes concessões. Por sua propria natureza de poder que interrompe, sinão as suas funcções, o seli trabalho durante um certo periodo do anno, que está menos em contacto com os factos diarios da administração do que o poder executivo, essa, como outras attribuições de caracter semelhante, não são da sua competencia, más sim, eram e são da competencia do poder executivo".

A esse criterio não deve ser extranha uma boa regulamentação legal da exploração da força hydraulica. Nas camaras municipaes em que a execução das leis competir a um só agente, nenhuma inconveniencia 
haverá em ser-lhe dada mais essa attribuição, dentro das condições previamente determinadas pela mesmas, instituições (24).

\section{Projecto apresenlado ao Congresso Paulisła e sua discussão}

O projecto apresentado, que, longe de ser obra bem acabada e perfeita, está pendente de exame e discussão no Congresso do Estado, obedece ás seguintes linhas geraes:

Em primeiro logar, reservando uma grande parte do patrimonio fiscal do Estado, que continúa a soffrer constantes usurpações, por outro lado promove, e impulsiona o aproveitamento regular das quédas de agua, pela sua immediata exploração, interessando ainda os Estados vizinhos, nos termos do art. 65, paragrapho $I .^{\circ}$ da Constituição Federal.

Em segundo lugar, attenta á falta de carvão de pedra, institue o projecto uma indispensavel reserva de força hydraulica das cachoeiras do Estado para a electrificação dos caminhos de ferro. Essa idéa moderna, do maior alcance pratico, aventada, pri-

(24) Uma providencia de caracter administrativo e que não pode deixar de ser attendida é a que diz respeito ao desenvolvimento da (psicultura). A ninguem deve ser permittido fazer barragens nos rios sem que tambem não construa escadas para os peixes. Essas escadas são pouco conhecidas entre nós, entretanto ha mais de vinte systemas diversos a respeito.

O Governo dos Estados Unidos do Norte, só para esse fim construiu seis escadas na cachoeira do rio Potomac (Maryland), cachoeira, aliás de 30 metros de altura. (Vide um art. sobre o assumpto na "Gazeta". desta Capital de 22 de Agosto ultimo, pelo engenheiro Lacerda Franco.

Poucu depois' de discutirmos o assumpto no Congresso do Estado, recebemos uma carra de $\mathrm{t}$ m lavrador de Campinas, datada de 5 de $\mathrm{Ja}$ neiro de 1899, fazendo sentir a necessidade de acautelar-se esse grande objectivo da alimentação publica. Dizia elle-"Acho a occasião opportuna para lembrar á V. Excia de estatuir clausulas obrigando aos empresarios a construir nas barragens escadas que facilitem aos peixes, a subida no tempo da desova, pois é sabido que nessa epocha elles precuram as nascentes para o desenvolvimento da prole». 
meiro na Italia, pelo ex-ministro Alfaro de Rivera, foi já consagrada em lei não só naquelle paiz, como na Suissa, na Allemanha e na Austria, onde uma commissão de engenheiros, presidida por Von Furstel, justificou recentemente a inovação "pelo poder egual senão maior das locomotivas electricas, pela carestia geral do combustivel, pela abundancia das quédas de agua e pelo terror do açambarcamento da força hydraulica pelas poderosas empresas industriaes.»

Finalmente, em terceiro logar, o projecto, organizando e unificando um importante ramo da administração publica, vem def̂nir a posição do Estado, que não póde nem deve, considerar-se alheio e indifferente ao novo e maravilhoso aspecto do mundo economico, em que, no conceito de um escriptor contemporaneo, todos nós nos agitamos sem saber para onde iremos arrebatados, tal é o progresso da electricidade! jecto :

Eis, em seus precisos termos, a integra do pro-

Projecto N. I6, DE I908. Sobre a utilizafão da forga hydraulica dos rios do Estado de S. Paulo.

O Congresso Legislativo do Estado de S. Paulo decreta:

ART, I. ${ }^{\circ}$ E' reservado o direito de propriedade do Estado sobre as quédas de agua situadas nas terras devolutas, não podendo serem dadas para a respectiva exploração no prazo maior de 25 annos, prorogaveis a juizo do governo.

$\int$ unico. Nas concessões para a exploração referida no art. precedente será reservado um quantum de força hydraılica que fôr necessario para a tracção electrica das estradas de ferro que, de futuro, tenham de ser concedidas ou encampadas.

Art. 2. ${ }^{\circ}$ As concessĩoes para a exploração nas terras devolutas, das quédas de agua para o apro. 
veitamento e distribuição de força, luz e calor serão sujeitas seguintes condições:

$\int_{\text {I }}^{\circ}$ O pretendente, empresa ou companhia que fôr organizada, além do respectivo requerimento, apresentará ao governo a planta do logar em que se acha a quéda de agua, com a indicação de sua posição relativamente ao ponto mais proximo servido por estrada de ferro e um anteprojecto de installação e dependencias a fazer para a exploração daforça hydraulica, com um orçamento approximado.

$\llbracket 2 .^{\circ}$ Com a planta, ante-projecto e todas as informações precisas, o pretendente, empresa ou companhia, apresentará uma exposição minuciosa acerca:

a)-das condifões technicas referentes á natureza das obras, bem como todas as informações necessarias para a completa descripção e justificação da concessão ;

b) -das condifões economicas referentes á installação em geral e em particular, tendentes a completar a justificação do projecto;

c) -das condifões commerciaes da exploração, comprehendendo tabellas onde constem os maiores preços que poderão ser cobrados pelo fornecimento de electricidade e para as installações nas vias publicas e domicilios.

ArT. $3 \cdot{ }^{\circ}$ Os favores a serem concedidos, conjunctamente ás concessões para a exploração referida no art. I $^{\circ}$ desta lei, são os seguintes:

$\int$ I. $^{\circ}$ Direito de desapropriação por utilidade publica dos terrenos e quaesquer bemfeitorias existentes fóra das terras devolutas e que forem necessarios para a exploraçâo, inclusive a formação de represas, para o assentamentos de fios conductores e abertura de estradas de ferro e de rodagem. 
$\$ 2 .^{\circ}$ Direito de estabelecer linhas telegraphicas, telephonicas e estradas de ferro e rodagem para uso exclusivo da exploração, e sem prejuizo de terceiros.

$\$ 3 .^{\circ}$ Isenção de quaesquer impostos estaduaes e municipaes durante a concessão.

$\$ 4 .^{\circ}$ Uma certa área de terras devolutas para a criaçâo de nucleos coloniaes, na forma das leis e regulamentos deste serviço.

$\int 5 .^{\circ}$ O concurso do governo do Estado junto aos poderes federaes para a concessão dos favores de que trata o decreto fecieral n. 5.646, de 22 de Agosto de 1905 .

Art. $4 \cdot^{\circ}$ Expedido o decreto de concessões, o concessionario, pela sua gestão, prestará no Thesouro do Estado uma caução de valor egual a tantas vezes mil réis quantos forem os kilowatts produzidos na respectiva usina, sendo que os numeros dos mesmos kilowutts será tomados pela capácidade dos geradores installados na usina.

$\int$ I $^{\circ}$ Além da caução, o concessionario annualmente entrará para o Thesouro do Estado com a mesma quantia, a titulo de fiscalisação da exploração.

$\$ 2 .^{\circ}$ O augmento da producção da energia determinará respectivamente o augmento correspondente da contribuição.

Art. $5{ }^{\circ}$ Antes de começarem quaesquer obras da exploração, o concessionario apresentará ao governo, o projecto definitivo de toda a installação, indicando as modificações e accrescimos feitos no ante-projecto.

ART. $6 .^{\circ}$ As canalizações poderão ser aereas ou subterraneas, a juizo do governo, mas sempre de accôrdo com o trafego geral, tanto das estradas como das ruas. 
ART. $7^{\circ} \mathrm{O}$ concessionario, de accôrdo com a legislação commum, responsabilizar-se-á expressamente pelos damnos ou prejuizos que, durante o goso da concessão, causem a terceiros pela inobservancia das disposições regulamentares.

ART. 8..$^{\circ}$ A concessão será declarada caduca sempre que o concessionario interromper a execução das obras por mais de tres mezes ou quando, depois de concluidas, deixar de fazer, por mais de quinze dias ininterrompidos, fornecimento da energia electrica ao publico, salvo os casos de força maior, a juizo exclusivo do governo.

Art. 9. ${ }^{\circ}$ Para os effeitos desta lei, serão necessarias concessões distinctas quando se tratar de quédas de agua cuja utilização para a producção de electricidade só puder ser feita por meio de mais de uma usina geradora.

ART. IO. Fica estabelecido o juizo arbitral para os casos de divergencia entre o governo e o concessionario, acerca da interpretação e execução das clausulas da concessão.

Art. I I O governo, para inteira execução dos contractos de exploração das quédas de agua, poderá impor multas até ao maximo de cinco contos.

Art. I 2. Fica o governo autorizado a promover e firmar convenios com os Estados do. Rio, Minas, Matto Grosso e Paraná sobre o aproveitamento das quédas de agua existentes nos rios que limitam e dividem os respectivos territorios.

Art. I 3. O capital do concessionario será fixado mediante approvação do governo e não poderá ser auginentado nem diminuido, sem sua autorisação.

ArT. I 4. Ao Estado fica reservado o direito de resgatar as propriedades do concessionario, em qualquer tempo, depois de vinte annos, contados da data do contracto. 
O preço do resgate será fixado de modo que, reduzindo a apolices da divida publica, produza uma renda equivalente a sete por cento do capital fixado pelo governo, deduzida a amortização correspondente ao numero de annos completo que já houver decurrido da data da inauguração ao primeiro fornecimento de energia electrica.

Art. i 5. Os concessionarios caso a sua séde não seja no Brazil, deverão ter um representante com plenos e illimitados poderes para tratar e resolver definitivamente, perante o administrativo e judiciario brasileiros, quaesquer questões que com elle se suscitarem no Estado, podendo o dito representante ser demandado e receber citação inicial e outras em que por direito, se exija citação pessoal.

Art. i6. Fica instituido, junto á. Secretaria da Fazenda, um registo especial das quédas de agua de propriedade do Estado, devendo a inscripção das quédas existentes nas terras devclutas ser feita mediante informações .e documentos enviados pela Secretaria da Agricultura.

Art. I 7. Fica o governo autorizado a organizar uma commissão de engenheiros, tirada do pessoal technico de que dispõe, para o fim especial de proceder o reconhecimento e estudo definitivo das quédas de agua existentes nas terras devolutas, publicando no paiz e no extrangeiro, os resultados desses estudos, afim de chamar para o assumpto, a attenção dos industriaes, quanto á vantagem do aproveitamento daquella riqueza natural inexplorada.

\section{DisPosições COMMUNS}

Art. i 8. Todo individuo, empresa ou companhia que, da data da presente lei em diante, quizer utilizar-se da força hydraulica existente, tanto aos rios 
publicos como nos rios particulares, para a exploração industrial da energia electrica, deve assignar um termo na secretaria da Agricultura, em o qual se obrigue, pelo onus da fiscalização, e a observar todas as prescripções preventivas de policia e de segurança em geral, das obras e installações que forem estabelecidas de accôrdo com a experiencia e os progressos da industria e das prescripções universalmente acceitas.

$§$ unico. Para a uniformização desse serviço, fica o governo autorisado a tomar extensiva a disposição do art. antecedente á todas empresas de electricidade existentes, depois de previo accôrdo com com as mesmas e mediante a concessão de quaesquer favores, de que trata o art. $3 .^{\circ}$

ArT. I 9. As camaras municipaes só poderão fazer concessão para fins industriaes da força hydraulica, quando se tratar de rio cuja nascente, todo o seu percurso e fóz sejam comprehendidos no territorio do respectivo municipio.

$\int$ unico. São reconhecidas as concessões que até a data desta lei, tiverem sido dadas pelas camaras municipaes.

Art. 20. Sómente o Estado poderá fazer concessões de utilização para fins industriaes da força hydraulica, quando se tratar de rio cuja nascente, todo o seu percuso e fóz sejam comprehendidos no respectivo territorio, salva a hypothese do aproveitamento da força hydraulica interessar serviços federaes, nos termos da lei federal n. 5.407, de 27 de dezembro de 1904 . trario.

Arr. 2I. Revogam-se as disposições em con-

Em seguida .vão as considerações que fizemos ao sustentar o projecto e que constam dos annaes da 
Camara dos Deputados d'aquelle anno. (25) (Sessão de I 4 de Setembro de igo8).

O Sr. Veiga Filho. - Sr. presidente, tendo o nobre deputado sr. João Sampaio iniciado a discussão deste projecto sobre a utılısasão da forsa hydraulı. cas dos rios, offerecendo-lhe um substitutivo, julgo-me forçado a voltar ao assumpto, fazendo uma nova explanação, no sentido de demonstrar que, havendo precedido á elaboração do projecto um consciencioso estudo e reflectivo exame, elle merece ser mantido em suas linhas geraes, em seu plano esboçado.

(25) No jornal «Evolução», de 24 de Setembro de 1908, foi publicado um interessante artigo sobre este projecto, onde foram externadas as seguintes apreciações:- "preoccupou-se em demasia quédas de agua situadas em rios que banham as terras devolutas ou de propriedade do Estado o que é apenas um detalhe da questão e descurou quasi completamente as disposições relativas á exploração das fontes de energia hydraulica existentes nos rios publicos que atravessam terras de propriedade particular.

Desejariamos que o illustre autor do projecto de que nos occupamos, enfrentasse mais resolutamente a questão.

S. exc., julgamos, poderia ter collocado a questão em termos mais positivos, definindo no seu projecto clara e francamente a propriedade do Estado sobre as quédas de agua existentes nos rios publicos, que se desenvolvem em todo o seu percurso dentro dos limites do seu territorio. E cumo consequencia da affirmação desse principio, poderia o projecto apresentado á camara dos deputados tratar não sómente das regras para ¿ fiscalização das obras e installações para aprcveitamento dessas quédas de agua, como principalemnte das condições para a respectiva concessão, salvaguardando a enorme riqueza publica que reside nessa.s fontes de energia, e que não deve passar para o particular sem que o Estado coparticipe directamente dos resultados.»

O illustrado articulista cujas honrosas referencias ao autor do projecto, agradecemos, não tem razão nos reparos feitos. A questão do patrimonio do Estado moderno não é de mero detalhe, é uma questão vital. Do desenvolvimento do dominio privado do Estado depende a diminuição la arrecadação tributaria e portanto um grande allivio para o povo que por toda parte vive esmagado pela obsessão fiscal.

No que diz respeito ao "definir clara e francamente a propriedade do Estado", não o fizemos por que em face da Const. Fed. fallece essa competencia aos Estados-d'ahi o haver accentuado a conveniencia da regulamentação da exploração hydraulica, enfeixando muito de proposito de todo o assumpto num só despositivo.

- Entre outros organs da imprensa que se occuparam do assumpto, não podemos deixar de assignalar a "Tribına Italiana", especialmente quanto ao editorial de 10 de Dezembro de 1908, cujos benevolos conceitos em relação ao autor do projecto tambem agradecemos 
O nobre deputado, cujos talentos reconheço, si não abandonar a região serena dos principios, conservando a inteira isenção de animo neste debate, acredito, dar-me-á toda razão, tanto mais quando acceito, de minha parte, algumas de suas principaes idéas, as quaes, não destruindo nem substituindo uma construcção já feita com paciente labor, poderão todavia contribuir para que ella seja uma obra bem acabada e digna desta assembléa legislativa que considero uma das mais esclarecidas de nossa patria.

$\mathrm{O}$ projecto, sr presidente, obedece a um systema préviamente adoptado; tem por base dois pontos capitaes, que acho não devem ser desprezados, pois de um lado, visa acautelar uma grande parte do dominio privado ou fiscal do Estado para o fim de ser explorado convenientemente, no interesse da collectividade, e não devastado ou arruinado por meio de toda a sorte de usurpações, e, de outro lado, sem accordar escrupulos, quanto a intricado ponto juridico, estabelecer preceitos geraes a que os proprios particulares ou proprietarios ribeirinhos se submetterão, attrahidos por incontestaveis vantagens.

Cuidar do dominio privado do Estado, na época actual, amplial-o ou desenvolvel.o, é contribuir para a formação de uma grande reserva tendente a fornecer auxilios aos governos para occorrer á despesa publica, sempre crescente, minorando o gravame dos impostos, que não devem ser como exclusivo recurso do fisco, visto não ser inexgottavel a bolsa do contribuinte.

Para justificar essa theoria, nâo preciso remontar ao ager publicus dos romanos, nem accentuar o pensamento das administrações precavidas ou previdentes que, no momento historico, a maior attenção prestam ao dominio privado do Estado nas suas diversas manifes. 
tações : - territorial, industrial, commercial, e fiscal, propriamente dito. Para justificar essa theoria não preciso ainda descer ao detalhe, como fiz por occasião de apresentar um projecto de lei sobre o patrimonio municipal desta capital, em cuja exposição de motivos citei factos assás curiosos, como o de um grande edificio publico federal, que foi tirado do abandono pelo reclamo causualmente feito por um incendio, e da existencia de ricas propriedades municipaes e estaduaes usurpadas por terceiros, anomalias que já se observa no tocante ás cachoeiras que se encontram nas terras publicas.

Si o projecto quanto á exploração da energia electrica visa, no mesmo tempo, attender ao interesse patrimonial do Estado, que deve ser subordinado a urn regimen contractual, e o interesse individual dos proprietarios ribeirinhos, inteiramente diverso sinão divergente, e que tem por si o direito commum--é manisfesto que tornam-se indispensaveis regras ou preceitos inteiramente separados e differentes.

O nobre deputado, divergindo desse modo de ver, que para mim é o assento da questão, disse: "Pareceu-me que essa disposiçâo do projecto éra por "demais restricta, e que, de accôrdo com a propria «epigraphe, sob a qual o seu illustre autor o desen* volveu, dever-se-ia tratar de regular a utilisação da " força hydraulica dos rios do dominio do Estado em "geral e não especialmente o aproveitamento das * quédas de agua existentes nas terras devolutas. Ef«fectivamente, si são propriedade do Fistado todos os rios " publicos existentes no seu territorio, o projecto, para * ser util e completo, deveria extender a regulamenta. "ção das concessões a todos rios navegaveis e ainda - aos rios que banham os Estados vizinhos, pois que - a faculdade privativa da União é apenas legislar sobre ‘a navegação.» 
Entretanto, para ver-se como o nobre deputado não emittiu suas idéas com toda a firmeza basta lermos o seguinte trecho do seu discurso:- "Podera o "projecto, alérn disso, conter disposiföes especiaes relati"vas ás concessões para a explorafão de mos ou quédas "de agua existentes nas terras devolutas, ainda que "esses rios não fossem comprehendidos na ordem dos "navegaveis ou de que se fazem os navegaveis, por"que mesmo assim pertencem ao Estado, como parte "do seu dominio patrimonial."

Concretizando o seu pensamento, no substitutivo ao projecto, o nobre deputado de modo generico assim formulou o art. $4 \cdot^{\circ}$ : — "As concessões serão feitas mediante decreto, e por prazo nunca maiores de 30 annos, prorogaveis a juizo do governo.»

Quer-se que a lei considere no mesmo pé de egualdade um pretendente que obtem uma cachoeira do Estado, para exploral-a mediante um simples requerimento - com outro que a tenha adquirido de particulares, depois dos maiores dispendios e sacrificios. Eis um grande defeito, sinão uma iniquidade do substitutivo. Ella não deve prevalecer para a exequibilidade da lei que se pretende decretar. Levantaria esse dispositivo, as mais graves questões e justos protestos!

Note-se que essa iniquidade sóbe de ponto, quando se vê que o substitutivo, não fazendo distinc. ção entre as cachoeiras do dominio privado do Estado, do dominio publico, do dominio particular, confundindo a encampação com o resgate, de modo generico assim preceitua, no art. $70^{\circ}:$ - Fica reservado ao «Estado o direito de resgatar as propriedades dos "concessionarios depois de sete annos, contados da "data da concessão.»

Não é possivel conceber-se uma disposição mais centralizadora, mais absorvente, mais contraria ao progresso industrial do que essa. 
O nosso projecto, ao contrario do substitutivo, respeita, em toda a integridade, o direito de propriedade, e apenas institúe, quanto ao seu uso e goso da mesma, os preceitos e regras geraes relativas á segurança publica. E', portanto, muito mais liberal.

Si encararmos este ponto capital que venho disdiscutindo, em face dos principios geraes do direito v. ex. ${ }^{a}$ sr. presidente, verá quanta razão teve o autor do projecto em não enfeixar, num só artigo as disposições relativas a todos os rios publicos e particulares como pretende o substitutivo.

Antes de tudo, tenhamos em linha de conta a grande divisão, a summa divnsio, dos rios que, segundo todos os tratadista, ou são publicos, de uso commum, ou são publicos patrimoniaes ou são particulares. Comquanto os bens patrimoniaes de um Estado, segundo Carlos de Carvalho (Consolzdafão, art. I $97, \mathbb{S} 3^{\circ}$, possam, por disposição de lei, tomar o caracter de uso commum e vice-versa, o certo é que sobre elles, assim como sobre os bens dos particulares, não ha nem pode haver divergencia alguma quanto ao livre uso, goso e disposição.

Em relação aos bens do dominio publico ou as cousas publicas, porém, o mesmo não se póde affirmar, com o consenso geral, e, ainda ha pouco, o governo do Estado do Rio teve de ouvir pareceres divergentes sobre a competencia do Estado em legislar sobre rios publicos, sendo talvez o mais notavel o parecer do jurisconsulto patrio dr. Bulhões Carvalho, que projectou muita luz a uma memoravel discussão travada na imprensa do paiz (26).

Além desse ponto delicado que obrigou o autor do projecto a cingir-se muito, quanto aos rios publi.

(26) Esse parecer foi publicado no "Jornal do Commercio» de 29 de Março de 1905, e a requerimento do autor figura nos annaes da Ca. mara dos Deputados de S. Paulo, anno de 1908 pag. 687. 
cos propriamente ditos e particulares, para não me referir a intricada questão da natureza ou difinição delles-ha a questão do direito de propriedade de taes rios que, segundo Teixeira de Freitas, é um as. sumpto mal definido na lei; é antes um ponto de facto que dará lugar a frequentes disputas, tal o valor economico que os nossos rios vão adquirindo! E a iniciativa do governo federal em confiar ao illustrado dr. Alfredo Valladão a organização do Codigo das Aguas outro fim não tem senão deixar o problema resolvido para todo sempre.

Eis o que escreveu, no projecto do Codigo das Aguas, o dr. Valladão: As cousas de uso commum constituem, verdadeiramente uma propriedade do Es. tado (União Federal); não se verifica, na hypothese, uma semples relação de tutela da administração, ou de direito suis generis ao menos como entendia a escola antiga.

A lição de Meucci é completa a respeito. Ao Estado (União Federal) na sua accepção propria e technica de povo organizado, pertence tanto a propriedade como o uso destas cousas; com a unica differença de que, em relação a propriedade que é um direito, o Estado se considera como unidade abstracta em relação ao uso como collectividade concreta. (Instituzioni di Diritto Aministrativo, pag. 339).

Accentuar estas noções, tel-as sempre em vista é de summa importancia na materia, pois a confusão della se deve em grande parte ao tumulto que reina geralmente nas legislação das aguas, dificillima, em já por si mesma, em virtude da imprecisão da nomenclatura hydrographica.

Em summa, em assumpto complexo como este, que offerece tantas difficuldades o papel do legislador estadual deve ser o mais reservado possivel, deve ser 
o mais cauteloso e discreto si quizer ter exito pratico nas suas deliberações, que vão formar, por assim dizer, nosso direito positivo, ou o modus vivendi do nosso povo, nesta ordem de cousas.

Para demonstrar a indiscutivel competencia do Estado quanto aos dispositivos do nosso projecto, constante dos artigos i 8 , I 9 e 20 que sómente interessam ao direito commum, em sessão de $\mathrm{I} 4$ de

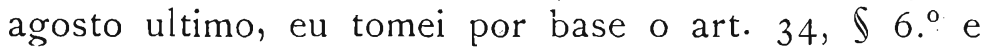

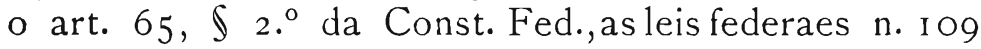
de r 4 de outubro de 1892 , o art. 23 da lei n. I 45 de 3 I de dezembro de 1903 e o decreto n. 5.407, de 27 de dezembro de 1907 , aos quaes me reporto por constituir a legislação remissiva ao caso.

Sr. presidente:-O nobre deputado, continuando sua critica ao projecto, disse: vejamos o $1^{\circ}$ artigo assim concebido: "E' reservado o direito de propriedade do Estado sobre as quédas d'agua situadas nas terras devolutas não podendo serem dadas para a respectiva exploração por prazo maior de 2.5 annos prorogaveis a juizo do governo.s $E$ accrescentou o seguinte:- "Ora si as quédas de agua não podem deixar de ser consideradas como partes dos cursos d'agua isto é dos rios, e si o dominio do Estado sobre todos os rios existentes nas terras devolutas é firme e incontestavel, parece que seria excusado estabelecer no projecto que o direito de propriedade das quédas de aguas é reservado ao Estado."

Neste importante dispostivo que deve ser mantido em toda a sua plenitude, o auctor do projecto teve em vista, difficultar, tanto quanto possivel, a alienação das cachoeiras existentes nas terras publicas, firmando o principio da conveniencia do perpetuo dominio do Estado sobre ellas. O Estado pode e deve reservar para todo sempre o seu dominio directo em razão da 
doutrina do patrimonio publico a que já nos referimos começar esta discussão.

Dahi a procedencia da reserva estabelecida, isso para não discutir em face do dominio publico dos rios navegaveis que alguns affectam ao Estado (União Brazileira) e não Estado federado, sem soberania.

Como o nobre deputado encarou por outra face este artigo do projecto, e eu em aparte lhe dei outro motivo, qual o de attender-se á conveniencia de uma consolidação de proveitos geraes em razão de considerações de ordem pratica-venho ainda demontrar que, ainda assim, esse dispositivo não é como disse:- "uma obra dispensavel e exorbitante das attribuições do Congresso.»

Para não citar inumeras leis estaduaes que têm contemplado em seus dispositivos preceitos geraes de direito, attentas as conveniencias da ordem pratica ou de mera consolidação, eu lembrarei apenas as cons. tituições deste Estado e as nossas leis eleitoraes.

E' verdade que a commissão encarregada pelo Congresso Legislativo de rever a Constituição do Esde I 4 de Julho de i89 I, ao emitir o seu parecer sobre a reforma, em 23 de Julho de igor - "viu-se obrigada a propor a eliminação de theses, algumas de preciosa materia, porém extranhas á Constituiçâo do Estado e que têm o seu assento natural na Constituição da Republica" mas não é menos certo que, ainda, assim manteve, pela conveniencia, disposições de direito commum, taes como as do artigo 55 da Constituição estadual, reconhecendo e assigurando os direitos de igualdade, liberdade, segurança e prosperidade, e as do art. 56 sobre a capacidade eleitoral, a qual

O sr. Foão Sampazo. - Mas podia ser excluidos, sem inconveniente algum, como foram excluidos os artigos da declaração de direitos. 
O sr. Verga Filho-. para ser definida, como disse o senador Herculano de Freitas, na sessão da Constituinte de 26 de maio de 1905 - «não depende da lei eleitoral da União, pois que a Constituição é tão obrigatoria para os Estados e o Estado não pode desconhecer o direito eleitoral do cidadão... Entretanto, a respeito disso, não só a Constituição de 9 de julho de 1905 , como a lei n. 2 I, de 27 de novembro de $189 \mathrm{I}$, que estabeleceu o regimen eleitoral, aquella no citado art. 56, e esta, no art. $2 .^{\circ}$, reproduziram quasi textualmente as differentes disposições do art. 70 da Constituição federal, as quaes por sua vez fazem tambem parte do recente regulamento n. I.4II, de ro de outubro de I906, na parte REFERENTE AOS ELEGIVEIS.

Sirvam-nos, portanto, os precedentes de anteparo á critica feita.

Outro ponto do projecto contra o qual se insurgiu o nobre deputado foi em relação ao $\$$ unico do artigo $1 .{ }^{\circ}$, que determina a reserva de um quantum, de força hydraulica que fôr necessario para a tracção electrica das estradas de ferro que tenham de ser concedidas e encampadas. Disse o nobre deputado: "que essa disposição constitue um empecilho ao livre desenvolvimento das industrias, ás quaes póde ser applicada a força hydraulica, já em ser, já transformadd em energia electrica" e argumentando com alguma razão, quanto ao ponto de vista economico, diz "que o aproveitamento da força, transformada em energia electrica, para a tracção das estradas de ferro não se póde dizer um problema completamente resolvido .»

Rebatendo esta affirmação lembro, primeiramente, que nós não estamos legislando sómente para o presente, mas tambem para o futuro que nos reserva as 
maiores surpresas em vista das multiplas e maravilhosas applicações da electricidade na producção da força, da luz e do calor.

Consideremos, porém, os nossos dias e vejamos o que se passa a respeito no extrangeiro e em nossa patria, sobre a electrificação dos caminhos de ferro, cuja importancia foi primeiro prevista pelo ex-ministro das Obras Publicas da Italia, Alfaro Rivera.

Eis o que se lê no Le Génie Cuvnl de 18 de julho, deste anno:- "Seguindo o exemplo da Suissa, da Suecia e da Italia, o governo austro-hungaro ordenou uma série de trabalhos ácerca deste momentoso problema. O resultado do inquerito feito por uma. commissão presidida por von Furstel, da Sociedade de Engenheiros Austriacos, foi reconhecimento do seguinte:- "um poder maior sinão egual ao das locomotivas electricas; a carestia do combustivel; a abundancia das quédas d'agua na Austria e o açambarcamento das quédas pela industria privada" A conclusão a que chegou uma commissão technica encarregada de estudar este assumpto, na Baviera, foi a seguinte:"Seria de interesse escolher as linhas cuja electrificação seria mais vantajosa è conservar disponiveis as quédas d'agua que fossem necessarias, não as concedendo sinão de accôrdo com clausulas que reservassem aos caminhos de ferro a energia de que tivessem necessidade, sem prejuizo de outros interesses industriaes».-Le Génze Covıl, de I I de julho ultimo.

Nos Estados Unidos, no Canadá e em diversos paizes da Europa, é $11 \mathrm{~m}$ caso já resolvido e posto em pratica, havendo diversas estradas de ferro movidas por electricidade. Como se vê de uma revista allemã aqui presente, os Estados do Ohio, Indiana o Michigan, já têm estradas de terro electrificadas numa extensão de 7 mil kilometros, salientando-se entre 
todas a de Cincinatti a Detroit, numa extensão de 500 kilometros, quasi como de S. Paulo ao Rio de Janeiro e como essa muitas outras estradas que vem ao caso referir.

Note-se que não falamos das estradas metropolitanas, subterraneas ou não, que servem para a locomoção nas yrandes capitaes como Londres, Paris, Berlim, Nova York e outras, onde centenas de kilometros de linhas electrificadas existem.

Em nosso paiz, o problema da electrificação dos caminhos de ferro foi primeiramente estudado pelo illustre engenheiro dr. Osorio de Almeida, que publicou a respeito um notavel parecer no Formal do Commercro de I 9 de outubro do anno passado.

A' cerca dessa innovação nos trens suburbanos da Central, escreveu s. exa. o seguinte:- "Entre essas medidas avultava a da electrificafão dos trens suburbanos, sinão pela sua importancia intrinseca, como interessando directamente o funccionamento economico do apparelho, que destino de muito maior alcance tem, ao menos como indispensavel accessoriamente á regularidede e normalização desse funccionamento; porquanto, si aos serviços propriamente nacionaes a que é destinada esta estrada não interessa directamente o dos suburbios desta capital, de natureza local e restricta, desenvolveu-se elle já de tal sorte que nem póde ser mais abandonado, nem descurado, impondo-se sua remodelação como imprescindivel, hoje, ao proprio desenvolvimento dos demais serviços de que carece ser, tanto quanto possivel, desprendido, para que thes deixe mais livre a natural expansão»

Si o colossal movimento dos trens de suburbios da Capital Federal, que em 20 annos elevou-se de 2.822 .858 passageiros a $\mathrm{I} 7.858 .385$, em I $906,(27)$ at-

(27) Ein 1908 o movimento dos trens de suburbios attingiu a 20.128.387 passageiros! 
testando a conveniencia da electrificação que por toda a parte é mesmo dispendiosa pela sua custosa installação -o que não succederá dentro desse periodo em S. Paulo, onde o progresso se mostra solidario de tradição em todos os élos da vida social?

Que surprezas estupendas não nos reserva $\mathrm{O}$ trafego das estradas de ferro de S. Paulo, as quaes, no anno findo de I90 $\bar{T}$, transportaram mais de cinco milhões de passageiros!

Porque, pois, o Estado, nas concessões para a exploração da força hydraulica existente nas terras publicas, ha de abrir mão de um grande interesse que lhes assiste, deixar de reservar um certo quantum da energia?

Não estamos vendo iniciados os estudos definitivos da electrificação da estrada de ferro que do Rio vai ter a Petropolis, numa extensão de 60 kilometros? Porque em relação a este assumpto empolgante $e$ maravilhoso havemos nós de preferir as trévas á luz, ou fechar os olhos a esse grandioso futuro que se nos antolha na exploração da hulha branca, que opulenta o territorio paulista?

Commetterá um grave erro, um erro sem perdão dos vindouros, o governo que permittir a exploração monopolizadora da energia electrica das terras publicas, sem reservar para a collectividade uma parcella dessa unidade electrica (kilo-watt), tão brilhantemente determinada pelo celebre electricista allemão, que lhe deu o nome.

- Criticando o art. $3 .^{\circ}$, paragrapho $3 .^{\circ}$, do projecto, que isenta as concessões de todos e quaesquer impostos estaduaes e municipaes, disse o nobre deputado:- «Parece-me que nessa disposição se encerra uma invasão da autonomia dos municipios pelo facto de se attribuir ao Estado o direito de isentar os con- 
cessionarios de quaesquer impostos municipaes. A concessão póde ficar isenta de todos os impostos es. taduaes, é fóra de duvida, uma vez que é o Estado que a faz. O Estado poderá ainda estabelecer que sobre a concessão não possam pesar onus ou tributos municipaes. Mas isentar o concessionario de quaesquer impostos municipaes em que possam incidir, não me parece que seja rasoavel.» Respondendo a esta arguição, não faço mais do que invocar a disposição contida no art. 20, n. 4, da lei organica municipal, n. I.038 de I 2 de dezembro de 1906 , assim espresso:- «As municipalidades não poderão tributar:-os bens e rendas federaes ou estaduaes e os serviços de concessão da União e do Estado.» Ora, pelo projecto a exploração da energia hydro-electrica é serviço de concessão estadual; essa energia faz parte do patrimonio, dos bens da propriedade particular do Estado e que são as terras publicas, $\log o$ não ha fundamento algum para duvida suscitada

A isenção assim declarada na lei ainda tem a vantagem de impedir que as camaras municipaes, contrariando o limite imposto á tributação, pelo \$ unico do n. I 3 , do art. i9, venham criar novos impostos, e a esse respeito é notoria a tendencia das camaras municipaes, que, em sua maioria, estão em pleno regimen da obsessão fiscal!

Quanto ao ponto de detalhe consistente em a isenção ir de encontro á renda municipal, já estabelecida, qual seja a do imposto predial, tambem não vejo razão, porquanto ás municipalidades, pela lei organica, compete a decretação do imposto predial ur. bano e o projecto cogita do imposto predial rural, visto serem as principaes installações das empresas de electricidade fóra do perimetro urbano, isto é, fóra da área occupada tão sómente pela urbs, como diziam 
os romanos. Aquelle imposto escapa da competencia municipal, não póde absolutamente ser lançado nem arrecadado pelas camaras. Eis os precisos termos do $\$$ unico, do n. I 3 , do art. I $9:-$ Nenhum outro imposto, taxa ou addicional, além dos estabelecidos na presente lei, poderão ser criados

Proseguindo na sua critica ao projecto, disse o nobre deputado:- $-\mathrm{Si}$, por um lado, o projecto avança pouco, restringindo as explorações em terras devolutas, a sua regulamentação, conforme acabei de expôr, e ainda porque se refere apenas ao aproveitamento das quédas d'agua quando as explorações podem ser feitas nos rios, independente das quédas; si, por um lado é deficiente, por outro lado vai muito longe quando no seu art. I 8, pretende fixar regras a que deve ficar sujeito o aproveitamento dos rios particulares, que no estado actual do nosso direito, escapam a qualquer regulamentação, por parte do Estado».

Relativamente ao ponto principal desta arguição ao projecto, prestou mão forte em sua defesa o nobre deputado o sr. Antonio Mercado. Não deveria dizer mais nada si não fosse preciso accentuar bem a conveniencia do onus da fiscalização, afim de serem evitados grandes perigos que offerecem todas as installações electricas.

Comquanto a lei italiana de 7 de junho de 1894 e seu regulamento de 28 de outubro de 1895 sejam muito recommendaveis, e dignos de attenta consulta, neste particular eu dou preferencia aos ensinamentos contidos na lei franceza de i5 de junho de igo6 (que abrogou a lei de 25 de junho de i 895) e o recente regulamento daquella lei, expedido a $2 \mathrm{I}$ de março do corrente anno.

$\mathrm{Na}$ legislação franceza, a distribuição da energia electrica que não se destina á transmissão de signaes 
(telegraphos) e a transmissão de palavras (telephones), não pode ser feita sem que primeiro sejam satisfeitas diversas condições technicas no ponto de vista da segurança individual, liberdade de circulação, como de serviços publicos, interessados, como especialmente de protecção á população rural. Ha tanto rigor nessas exigencias, que o art. I 9 da lei, aliás examinada com todo cuidado, estatue o seguinte: - "Ces conditions seront souminses á une revision annuelle». E o art. 25, pelas infracções, além das penalidades previstas no Codigo Penal, estabelece fortes multas impostas pelos tribunaes correcionaes, sendo de 16 a tres mil francos. Neste art., accrescenta o legislador:- «Nes délits et contraventions pourront être constatés par de procés verbaux, drésses par les officiers et police judiciare, les ingenieurs et agents des ponts et chaussèes et des mines, les ingénieurs et agents du service de télégraphes, les agents municipaux chargés de la surveillence ou du contrôle et les gardes particuliers du concessionaries, agréés par l'ádministration et dûment assermentés. Ces procés verbaux feront foi jusqu'á preuve du contraire».

Eis, sr. presidente, a ultima palavra, ou a mais recente disposição a respeito do assumpto, encontrada na legislação dos povos cultos. Entretanto, o nobre deputado, não acceitou uma disposição generica relativa ao assumpto, convenientemente incluida no art. 18, assim, ainda se exprimiu:- —Parece-me são outras tantas limitações do direito de propriedade, que para ser exercido não depende de uma fiscalização especial e onerosa, nem de conformar-se o proprietario obrigatoriamente com os progressos industriaes».

Lamento estar em completo desaccordo com semelhante affirmação, contra a qual, todos os dias, estão protestando innumeros desastres occasionados 
pela electricidade. Não resisto ao praser, de, a proposito, citar um trecho de um iilustrado engenheiro: "As longas linhas de transmissão estão sujeitas a inumeros contra-tempos e accidentes; ellas têm tres inimigos:- o céo, a terra e os homens. "Nós eliminamos o céo pelo para-raio; a terra pelos excellentes isoladores; mas a imprevidencia, a impericia dos homens são impossiveis de serem vencidas; até a maldade delles, pois, não raro, fazem dos isoladores aereos um alvo cubiçado para os exercicios do tiro, o que só uma vigilancia muito apurada pode impedir».

Seja-me permittido neste ponto salientara legislação do Estado do Rio de Janeiro, que um grande subsidio offerece para a solução do problema. O decr. n. 9 Io, de 29 de março de 1905 do governo daquelle Estado e a lei n. 7 i 7, de 6 de novembro do mesmo anno são muito minuciosos, e, em tanto quanto possivel, satisfazem ao desideratum da fiscalização na exploração electrica.

No tocante ao emprego da palavra-quédas d'agua - ainda mais uma vez não assiste razão para ser extranhada. Bem sei, sr. presidente, que como diz o dr. Mario Ramos:--"pode-se utilizar "como energia hydraulica as aglias tranquillas dos lagos, dos reservatorios, ou as aguas correntes dos riachos, das torrentes e dos rios caudalosos, tudo é energia potenczal, que será aproveitada e transformada com mais ou menos artificio technico» Mas o que não posso comprehender, é que, em qualquer uma dessas explorações falte a quéda, por menor que ella seja, sem a qual os technicos não distinguiriam a montante e a jusante das mesmas.

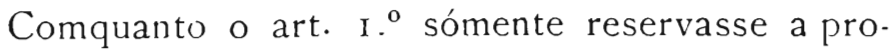
priedade do Estado sobre as quédas existentes nas terras devolutas e não sobre aquellas provenientes de 
grandes represas feitas nos rios, as quaes, para o aproveitamento serão de um custo muitissimo maior, devendo, portanto, serem necessariamente distinguidas, attentos os enormes sacrificios empregados para obtelas -eu não faço, de minha parte, questão alguma de acceitar uma emenda de redacção, interpretando mais genericamente a hypothese, com o que só terá que lucrar o interesse publico.

Da mesma fórma acceitarei uma emenda quanto á redacção do art. I6, afim de que o registo alli indicado seja referente apenas ás cachoeiras de propriedade particular do Estado-comquanto julgue que alguma cousa nesse sentido devia ser feito, em relaçâo ás cachoeiras ou exploração hydraulica pelos particulares, para os fins da estatistica. Em todo o caso, a providencia contida no projecto de lei, não fez mais do que consagrar a pratica, já instituida pela nossa contabilidade publica, ex-vı do dec. fed. n. I.335, de I 2 de dezembro de 1905 .

Para esse registo especial, que opportunamente fôr feito, além das cachoeiras de propriedade patrimonial do Estado, indicadas no quadro que organizei e que serviu de fundamento ao projecto-ha muitas outras, como as que fazem parte de uma informação que gentilmente enviou-me um illustrado engenheiro, e que deverão ser publicadas, como documento, conjuntamente com este discurso.

O nobre deputado terminou o seu discurso, affirmando a existencia de uma omissão ou falha sensivel no nosso direito civil, quanto ao aproveitamento da força hydraulica, onde existe, ou á distancia em cuja hypothese deve ser transportada, por meio de uma levada de agua ou aqueducto, ou por meio de conductores electricos. 
Disse s. exa.:

"A nossa legislação, antiquada como é, não podia absolutamente prever casos que só o estado actual da nossa civilização tem criado. Entretanto, já existe, mesmo 110 direito antigo, a servidão legal de aqueducto, para aproveitamento de aguas de rios publicos ou particulares, quando esse aproveitamento seja em beneficio da agricultura. Além disso, nada mais se encontra no nosso direito privado. Seria, pois, de grande utilidade, de alta conveniencia, não sómente extender servidão legal existente a todos os casos, a todas as explorações industriaes, em vez de mantel.a limitada á industria agricola, como tambem criar a servidão legal de conductores electricos, quer com relação aos predios urbanos, quer com relação aos predios ruraes"

Neste sentido s. exa. fez um appello ao Congresso Nacional, iniciativa essa muito digna de applauso. Entretanto cumpre reconhecer que a omissão não é tão sensivel como parece, á vista do que dispõe a Consolidação das leis civis de Teixeira de Freitas que, no art. 8.94 I assim estatue:- "As aguas dos rios e ribeiros podem ser occupadas por particulares; e desviadas por canaes ou levadas em beneficio da agri. cultura e industria".

Em nota, sob n. I 2, o eminente jurisconsulto accrescenta que este dispositivo baseia-se no alvará de 27 de novembro de 1804 , paragrapho i I, applicado ao Brasil pelo alvará de 4 de março de i $\$$ ig. "Esta legislação, continúa aquelle jurisconsulto, dava direito ao proprietario de fazer canaes ou levadas para regar as suas terras, ou para exgottar as innundadas; requerendo ao juiz, mediante o parecer de louvados a designação de logar mais commodo, ainda mesmo em terrenos alheios; e sendo indemnizados os donos desses terrenos dos prejuizos que soffressems 
$\mathrm{O}$ dr. Alfredo Valladão que estudou com grande competencia o nosso regimen juridico ácerca das aguas, na exposição de motivos que precede ao projecto sobre o Codigo das Aguas da Republica, assim opina: — "Pelo regimen do alvará não está expresso que esta servidão aproveita á industria. $E^{\prime}$ certo que entendi, em outro logar, que ella aproveitava a industria, pelos seguintes motivos: Si é verdade que o alvará de 1804 baixou para attender aos interesses da lavoura, não é menos certo, porém, que elle estabeleceu a servidão de que se tratâ, não só para a rega de terras, como para o movimento de engenhos. Ora, o emprego da palavra engenhos, não deixa duvida a respeito; aquella servidão aproveita á industria. E assim parece ter entendido Teixeira de Freitas, quando, com assento no referido alvará, refere.se á derivação da agua para beneficio da agrucultura $e$ industra».

Como se vê, é um destes casos em que muito poderia adiantar a jurisprudencia dos nossos tribunaes, todavia, eu não estou em desaccordo com o appello do nobre deputado.

Sr. presidente, o assumpto, em debate, é realmente da maior revelancia e magnitude, sobretudo pelas maravilhosas e infinitas applicações da electricidade na vida social, salientando-se entre ellas, a da industria electro-metallurgica e da electro-chimica que com o advento do forno electrico, surgem, surprehendendo a todos, annunciando uma breve revolução no mundo industrial moderno.

Si fui prolixo neste meu discurso, respondendo ao nobre deputado, meu companheiro de representação pelo $8 .^{\circ}$ districto - a isso me levou o justo intento de demonstrar á casa, que, á elaboração do projecto precedeu o maior esforço intellectual, representando ainda um estudo conscencioso; fructo de 
penoso labor, que não merece ser totalmente refundido ou substituido, embora elle necessite de modifificações e reparos.

Peço ao nobre deputado que não extranhe a sinceridade e lealdade com que exprimo o meu modo de sentir; si alguma palavra por mim proferida causa-lhe desagrado, ou fére, mesmo de leve, a sua susceptibilidade, eu, de bom grado, darei uma immediata explicação, de modo que não fique o menor resentimento de sua parte.

Apresentando um requerimento para que o projecto volte á commissão de justiça, afim de emittir novo parecer, eu, mais uma vez, quero assignalar a grandeza e excellencia da empresa ora affecta á sabedoria desta camara.

Trata-se de regular a exploração da energia electrica, ainda em inicio do seu desenvolvimento, como attestam os docs. que offereço afim de serem publicados; dessa eneryia desaproveitada que, até este momento, excede de um terço ao coefficiente dos cavallos hydraulicos conhecidos nos Estados da Norte America - tal a riqueza potencial e privilegiada dos nossos rios que em diversas direcções córtam o bello territorio paulista!!

Sr. presidente, imaginemos essa fabulosa fortuna representada pela nossa lavoura de café, uma das mais importantes do globo; imaginemos a opulencia das nossas terras, o valor das nossas manufacturas que tamanha expansão têm tido, nestes ultimos annos; imaginemos o capital empregado em nosso systema ferro-viario e em todos os nossos emprehendimentos industriaes; pois bem, todo esse grandioso conjuncto em breve tempo estará muito aquem do valor sómento da força hydraulica inexgottavel, perenne, existente nas terras publicas de propriedade particular ou patrimonial do Estado!» 


\section{Dados informativos e numericos}

Damos em seguila 0 quadro demonstrativo das PRINCIPAES CACHOEIRAS E SALTOS existentes na região das terras devolutas do Estado exclusive as corredeiras, segundo dados extrahidos dos trabalhos da Commissão Geographica e Geologica do Estado.

\begin{tabular}{|c|c|c|c|c|c|}
\hline RIOS & CACHOEIRAS & SALTOS & $\begin{array}{c}\text { Propriedade do } \\
\text { Eslado }\end{array}$ & $\begin{array}{l}\text { Propriedade não } \\
\text { reccnhecida }\end{array}$ & $\begin{array}{c}\text { Força } \\
\text { en cavallos }\end{array}$ \\
\hline Tiete, & $\begin{array}{l}\text { Macuco } \\
\text { Cruzes } \\
\text { Illha Secca }\end{array}$ & $\begin{array}{l}\text { Avanhanda } \\
\text { va } \\
\text { Itapura }\end{array}$ & $\begin{array}{l}\text { Não reconhecirl } \\
\text { Em parte }\end{array}$ & : & $\begin{array}{l}\left\{\begin{array}{c}\text { Mais de } \\
40.000\end{array}\right. \\
61.600 \\
57.700\end{array}$ \\
\hline Paraná & . & $\begin{array}{l}\text { Urubú - pun. } \\
\text { gá }\end{array}$ & Em partc & 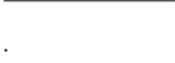 & $447.000 ! !$ \\
\hline $\begin{array}{c}\text { Aguapehy } \\
\text { e do } \\
\text { Peixe }\end{array}$ & $\begin{array}{l}\text { Iboporá } \\
\text { Commis Geo- } \\
\text { graphica. } \\
\text { Maribondos } \\
\text { Manchas }\end{array}$ & $\begin{array}{l}\text { Dr. Carlos } \\
\text { Botelho } \\
\text { Biguá } \\
\text { Guatiava. } \\
\text { Guachos. }\end{array}$ & Estado & : & Ignorada \\
\hline $\begin{array}{c}\text { Ribeira de } \\
\text { Iguape }\end{array}$ & $\begin{array}{l}\text { Varador } \\
\text { Caracol } \\
\text { Funil } \\
\text { Feid. . . } \\
\text { P. Vermello. } \\
\text { Januario } \\
\text { Paulistas } \\
\text { Estreito } \\
\text { Caracinha. } \\
\text { Brejaúva }\end{array}$ & i. & i. & $\left\{\begin{array}{l}\text { Não reco- } \\
\text { nhecida }\end{array}\right.$ & Ignorada \\
\hline $\mid$ & $\begin{array}{l}\text { Grande } \\
\text { Lageaclo. } \\
\text { Saltinino. } \\
\text { Piuva } \\
\text { Espelho, } \\
\text { Inferno } \\
\text { Cachoeira de S. } \\
\text { Lourencinho } \\
\text { Cac'hoeiras de } \\
\text { Itariri. }\end{array}$ & Faini & Estadu & 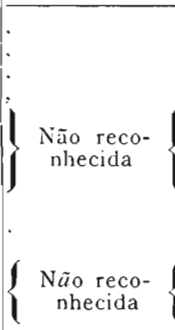 & lgnorada \\
\hline $\begin{array}{l}\text { Rio Para- } \\
\text { panema }\end{array}$ & $\begin{array}{l}\text { Capivara } \\
\text { Pyau. } \\
\text { Larangeira } \\
\text { Reboju } \\
\text { Pedregulho } \\
\text { S. do Diabo } \\
\text { Tayniú } \\
\text { Estreitu. } \\
\text { Palmital }\end{array}$ & i. & Estado & : & lgnorada \\
\hline $\begin{array}{c}\text { Rio } \\
\text { Grande }\end{array}$ & Maribondo. & $\begin{array}{l}\text { Patos. } \\
\text { Onça }\end{array}$ & $\begin{array}{l}\text { Em parte } \\
\text { Em parte } \\
\text { Estado }\end{array}$ & : & $\left\{\begin{array}{l}\text { Mais de } \\
600.000 ! !\end{array}\right.$ \\
\hline $\begin{array}{c}\text { Juquery- } \\
\text { qere }\end{array}$ & $\begin{array}{l}\text { Muitas cachoci- } \\
\text { ras. }\end{array}$ & & Estado & . & 50.000 \\
\hline Rio Branco & Monos o Capivary & . & Estado & . & Mais de 15.000 \\
\hline $\begin{array}{l}\text { Vertentes da } \\
\text { serra do mar }\end{array}$ & $\begin{array}{l}\text { Muitas cachoei- } \\
\text { ras }\end{array}$ & 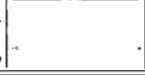 & Estado & . & Ignorada \\
\hline
\end{tabular}




\section{$-233-$}

Em seguida se encontra uma lista das uzinas electricas existentes neste Estado, em 24 de Agosto de igro, e por onde se verifica o progresso havido na exploração da força hydraulica e a confirmação do que o dr. Mario Ramos disse:- - S. Paulo é o berço do aproveitamento da hulha branca no Brazil»

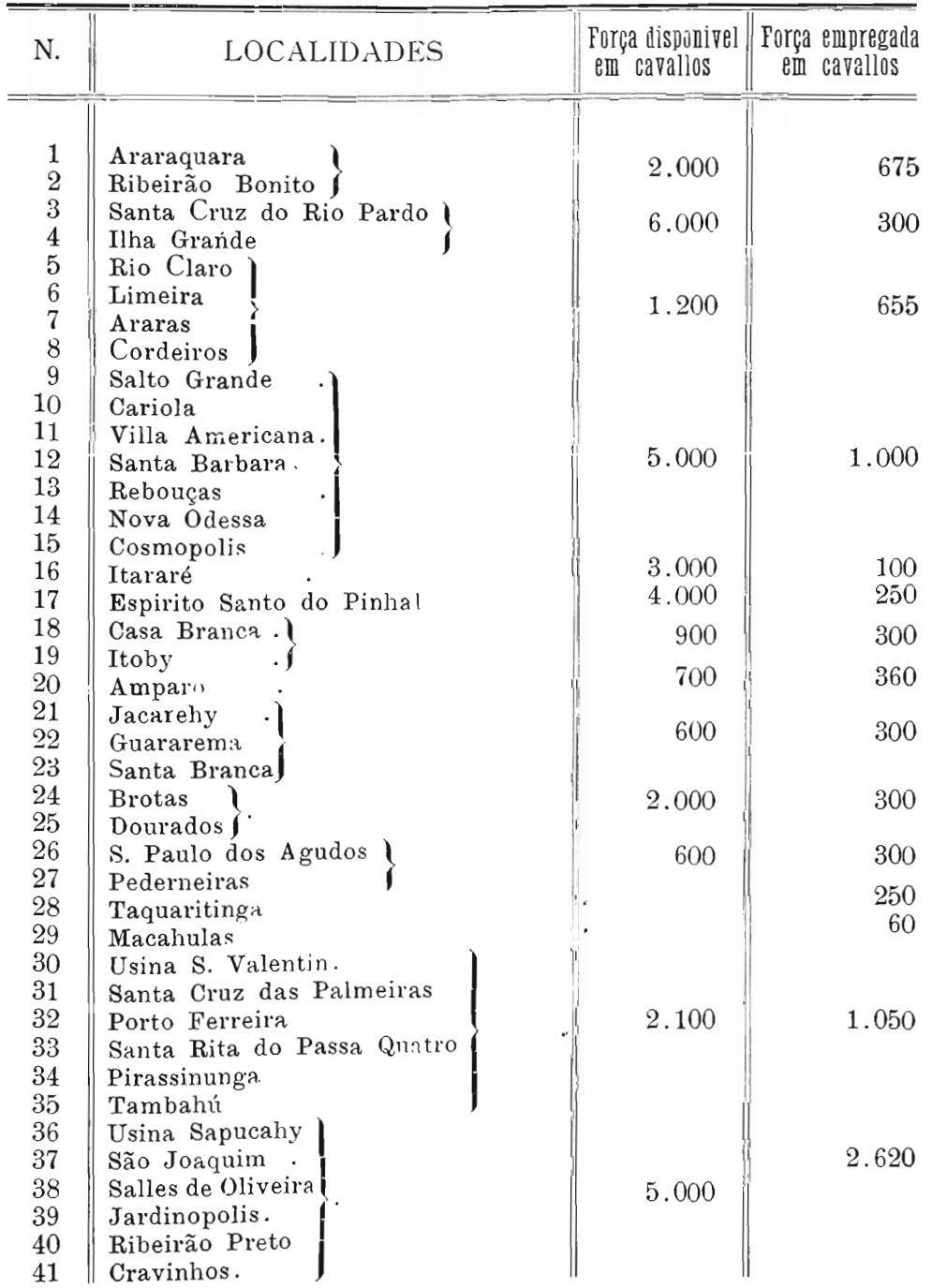




\begin{tabular}{|c|c|c|c|}
\hline N. & LOCALIDADES & $\begin{array}{c}\text { Força disponivel } \\
\text { em cavallos }\end{array}$ & $\begin{array}{l}\text { Força empregada } \\
\text { em cavallos }\end{array}$ \\
\hline $\begin{array}{l}42 \\
43 \\
44 \\
45 \\
46 \\
47 \\
48 \\
49 \\
50 \\
51 \\
52 \\
53 \\
54 \\
55 \\
56 \\
57 \\
58 \\
59 \\
60 \\
61 \\
62 \\
63 \\
64 \\
65 \\
66 \\
67 \\
68 \\
69 \\
70\end{array}$ & $\begin{array}{l}\text { Sorocaba. } \\
\text { Pedras. } \\
\text { Jahú } \\
\text { Mococa } \\
\text { Itatinga (Santos) } \\
\text { Descalvado. } \\
\text { Franca. } \\
\text { Batataes } \\
\text { Serra Negra } \\
\text { Itapira } \\
\text { Bragança } \\
\text { Piracicaba } \\
\text { São Manoel } \\
\text { Tieté } \\
\text { Baurń } \\
\text { Cunha Bueno. } \\
\text { Coronel Procopiu } \\
\text { Ituverava } \\
\text { Igarapava } \\
\text { Joboticabal } \\
\text { Bebedouro } \\
\text { São José dos Uampus } \\
\text { Caçapava } \\
\text { Usina Esther } \\
\text { Piracaia } \\
\text { Dois Corregus } \\
\text { São Carlos: } \\
\text { Jundiahy } \\
\text { São Paulo (Light \& Pı) wer) }\end{array}$ & $\begin{array}{r}20.000 \\
5.000 \\
1.200 \\
25.000 \\
\text { Ignoradi } \\
n\end{array}$ & $\begin{array}{r}2.000 \\
275 \\
2.000 \\
600 \\
25.000{ }^{(1)} \\
400 \\
300 \\
200 \\
250 \\
200 \\
600 \\
750 \\
550 \\
250 \\
200 \\
120 \\
70 \\
200 \\
500 \\
600 \\
200 \\
200 \\
200 \\
200 \\
150 \\
350 \\
400 \\
850 \\
32.000\left(^{(}\right)\end{array}$ \\
\hline & & 84.000 & $80.000\left({ }^{3}\right)$ \\
\hline
\end{tabular}

(1) Até o numero 45 comprehendem-se usinas electricas executadas pela conceituada casa Bromberg, Hacker \& Comp. rua da Quitanda N. 10 a qual devemos alguns dados aqui reunidos.

$\left({ }^{2}\right)$ Estes algarismos comprehende as novas installações.

$\left(^{3}\right)$ Neste numero só estão incluidas as intallações proveniente das quédas d'agua. 


\section{$-235-$}

\section{VII. - Legislação relerida e conclusão.}

Legislaf̧ão referida. Como uma contribuição para os que estudarem mais amplamente o interessante assumpto que constitue objecto deste nosso imperfeito trabalho, achamos de conveniencia indicar as seguintes fontes de consulta immediata: (28)

A Ord. Ph. Liv. 2, tit. $26 \$ 8$; alvarás 27 de Novembro de 1804 e de 4 de Março de 1819 e bem assim a lei n. I.507, de 26 de Setembro de I 867 , quanto ás servidões ;

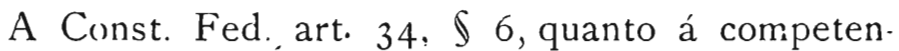
cia exclusiva federal em legislar sobre navegação, náda dispondo quanto á força hydraulica, e o art. $35 \mathrm{n}$. 2 , quanto á competencia, não privativa, relativamente ao assumpto, e o art. 65 ns. I e 2, quanto aos convenios estaduaes sem caracter politico, e n. 2 , quanto á esphera da competencia estadual;

- A lei fed. n. Io9, de 16 de Outubro de i 892, que, $e x$-vi do art. I 3 da Const. Fed., veio fixar os casos da competencia dos poderes estaduaes para resolverem sobre o estabelecimento de vias de communicação fluviaes e terrestres entre a União e os Estados e destes entre si. Lei orçamentaria federal n. I I 45, de 3 I de Dezembro de I903, art. 23 quanto ao aproveitamento da força hydraulica para a transformação da energia electrica applicada a serviços federaes.

- O dec. fed. n. 5.407, de 27 de Dezembro de I904, que regula o aproveitamento da força hydraulica para a transformação em energia electrica applicada a servifos federaes.

(28) Idem, os Acc. do Sup. Trib. de 18 de Novembro de 1896 ; de 28 de Dezembro de 1907, quanto á competencia estadual, e que indirectamente firmam a verdadeira doutrina sobre concessões para a exploração hydraulica. 
- O dec. fed. n. 5.646, de 22 de Agosto de 1905, que regula a concessão de favores ás empresas de electricidade gerada por força hydraulica que se constituirem para fins de utilidade e conveniencia publica.

- Lei orç. fed. n. 1.617, de 30 de Dezembro de 1906, art. 35 n. XVIII, lettra $a$, quanto á substituição da tracção a vapor pela electricidade no serviço dos suburbios da Estada de F. Central do Brazil. - Lei do Estado de S. Paulo, sob n. 30, de I 3 de Junho de 1892 , que define a competencia estadual e municipal quanto ás linhas de bonds.

-Decreto do Governo do Estado do Rio de Janeiro n. 9 Io, de 29 de Março de 1905.

- Lei do Estado do Rio de Janeiro n. 7I7, de 6 de Novembro do mesmo anno.

Conclusão. Não faz muito tempo, uma revista extrangeira, comentando alguns insuccessos nas empresas de mineração, em nosso paiz, comparou, per. versamente, os nossos governos ao dragão da fabula, que guardando immensos thesouros, para ninguem aproveitar-se delles, sucumbiu, por final, entre os extremos da penuria.

Semelhante allusão funda-se no facto de, ainda, em nosso paiz, não ter sido possivel implantar-se o regimen Torrens que fez, em grande parte, a prosperidade de Australia, sendo immediatamente adoptado na Inglaterra e Norte America.

Realmente instituido o registro Torrens ficaria garantido por todo sempre, a legitimidade dos titulos acquisitivos da propriedade, não mais prevalecendo sobre ella contendas judiciarias que, não raro, durando annos, afugentam a exploração industrial.

(29) Léon Donnat, "Le Politique Expérimentale», pag. 101. 
- No que diz respeito á exploração da força hydraulica dos nossos rios, dessa fabulosa riqueza que, como por encanto, surge em meio dos explendores da nossa natureza, certamente não ficaremos adstrictos á rotina secular identica e os nossos legisladores e governos tudo farão para abrir.se essa fonte de inexhau. rivel opulencia, ao engenho humano.

Desbravando os nossos sertões, descobrindo e divulgando as nossas riquezas naturaes, até hoje desconhecidas, entregando-as ao genio industrial de todos quantos têm a felicidade de palmilhar esta terra cosmospolita, nossa administração publica saberá desmentir aquelle injusto conceito e assim enaltecer e impulsionar a iniciativa paulista!

Dr. Veiga Filho.

24 de Agosto de igio. 